
Dr Miodrag Regodić, potpukovnik Vojna akademija, Beograd

\section{DALJINSKA DETEKCIJA KAO METOD PRIKUPLJANJA PODATAKA O PROSTORU}

UDC: 629.7 .066

$520.62: 355.535$

Rezime:

Zbog potrebe da se dobiju novi podaci, da osmatranja i izučavanja budu objektivnija od dosadašnjih sinteza prihvaćen je novi istraživački metod-daljinska detekcija. U radu su predstavljeni principi i elementi daljinske detekcije, kao i neke od mogućnosti korišćenja informacija daljinske detekcije za vojne potrebe.

Ključne reči: daljinska detekcija, elektromagnetna energija, snimak, senzor, informacija.

\title{
REMOTE SENSING AS A METHOD OF SPACE DATA ACQUISITION
}

Summary:

In order to gather new information and to make observations and examinations much more objective than existing syntheses, a new examination method-remote sensing-has been adopted. The paper deals with the principles and elements of remote sensing as well as with some possibilities of using remote sensing information for military purposes.

Key words: remote sensing, electromagnetic energy, image, sensor, information.

\section{Uvod}

Gotovo da nema poznate metode, naučne discipline ili naučne oblasti koje su imale tako intenzivan i brz razvoj kao daljinska detekcija. Sa savremenom tehnologijom rada i visoko usavršenom opremom i programskom podrškom ona je za veoma kratko vreme postala opšteprihvaćeno naučno područje i nezamenljivo sredstvo u svim sferama života. Daljinska detekcija je uz aerofotogrametriju nezamenjiv metod masovnog prikupljanja podataka o prostoru.

Daljinska detekcija u užem smislu obuhvata analizu i interpretaciju različitih snimaka delova Zemljine površine, načinjenih sa površine terena, iz vazdušnog prostora ili iz kosmosa. Početak nje- ne istorije mogao bi biti nastanak klasične fotografije, koja se javlja 1839. godine i vezuje za ime Francuza Dagera (Daguerre). Deset godina kasnije (1849), u Francuskoj fotografija počinje da se primenjuje pri izradi topografskih karata.

Naziv daljinska detekcija je slobodni prevod engleskog termina Remote Sensing. U francuskoj literaturi ovaj termin se prevodi kao Teledetection, u nemačkoj Fernerkundung, a u ruskoj дистанционние исследования.

Kod nas se, prema korišćenom literaturnom izvoru, pojavljuju i nazivi ,daljinska opažanja“, „daljinska istraživanja“, „teledetekcija“, ,daljinski metodi“, „distanciona istraživanja“. Pojam daljinska detekcija je najčešće u upotrebi. 
Najpogodniju definiciju daljinske detekcije dala je Evelin Pruit 1960. godine koja glasi: „Daljinska detekcija predstavlja metod prikupljanja informacija putem sistema koji nisu u direktnom, fizičkom kontaktu sa ispitivanom pojavom ili objektom“".

U stranoj literaturi srećemo i definiciju po kojoj je daljinska detekcija nauka (u širem smislu i umetnost) o prikupljanju podataka o Zemlji bez fizičkog kontakta sa njom. Podaci se prikupljaju registrovanjem i snimanjem odbijene ili emitovane energije objekta i obradom, analiziranjem i korišćenjem tog podatka [1].

Obe definicije, kao i druge, vide daljinsku detekciju kao postupak izviđanja i snimanje Zemljine površi iz vazdušnog prostora, svemira ili sa Zemlje, bez kontakta sa površinom Zemlje. Danas se pod terminom daljinska detekcija podrazumeva i aerofotogrametrija uz uvažavanje specifičnosti fotografskog nastajanja snimka.

\section{Princip i primena daljinske detekcije}

Pri realizaciji postupaka daljinske detekcije jasno se može definisati i izdvojiti nekoliko direktno povezanih elemenata. U geonaukama, među koje spada i geodezija, objekat je fizička površina Zemlje. Objekat zrači elektromagnetnu energiju, koja nosi informacije o njegovim osobinama. Energija može biti sopstvena i reflektovana, koja je saopštena objektu iz prirodnog ili nekog veštačkog izvora.

Energiju registruje senzor, koji se u najvećem broju slučajeva nalazi na pokretnoj platformi (Zemljinom sateli- tu). Na osnovu složenog elektronskog sklopa senzora registrovani signal prevodi se u oblik pogodan za obradu, odnosno nastaje odgovarajući snimak $u$ digitalnom ili analognom obliku. Zatim, sledi analiza snimljenog područja, interpretacija rezultata $i$, na kraju, upotrebljiva informacija (podatak) o snimljenom sadržaju. Ta informacija najčešće obuhvata saznanje o vrsti, granicama prostiranja i intenzitetu registrovanog fenomena. Princip daljinske detekcije se jednostavno može sagledati na osnovu slike 1.

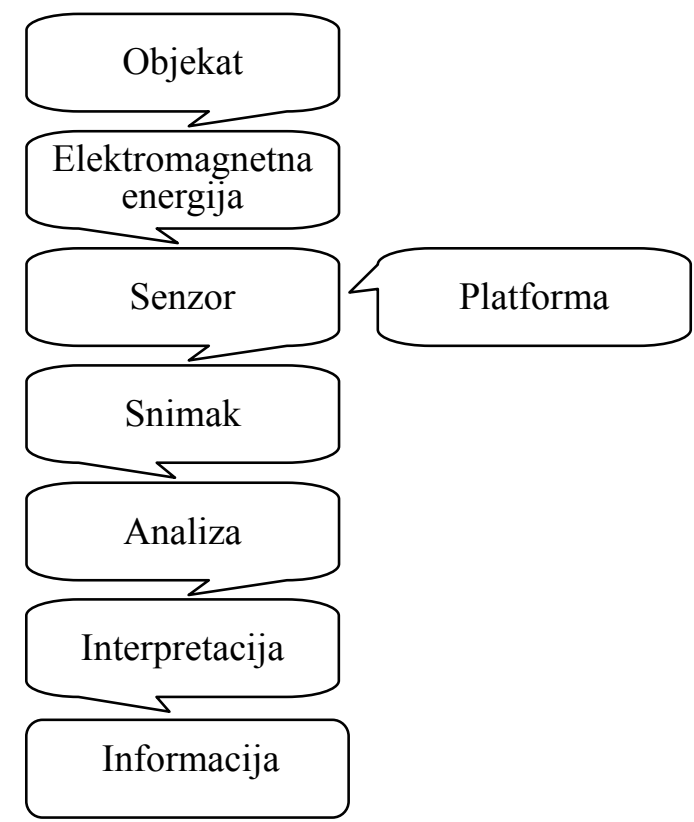

Sl. 1 - Princip daljinske detekcije [5]

Osnovni elementi koji učestvuju u postupku daljinske detekcije su (slika 2): objekat - predmet istraživanja - A; elektromagnetna energija - $\mathrm{B}$; senzor, platforma - $\mathrm{C}$; snimak, analiza, interpretacija - D; informacija za upotrebu - obrađeni podatak daljinske detekcije - E. 


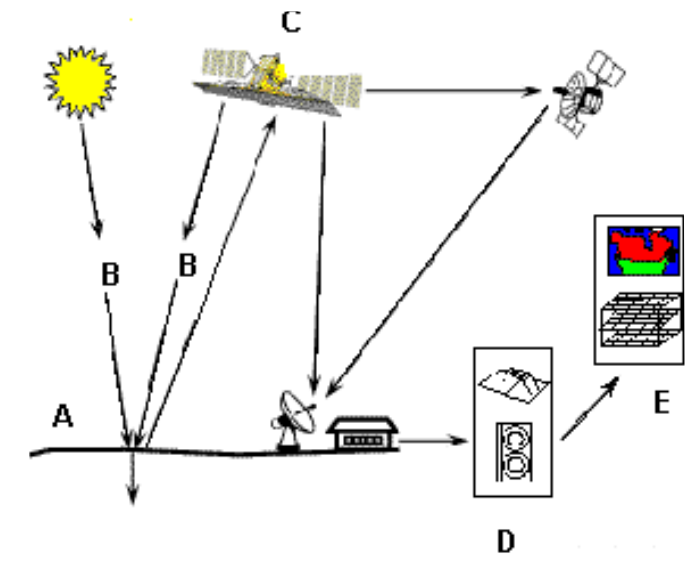

Sl. 2 - Osnovni elementi daljinske detekcije [2]

U oblastima geodezije i kartografije daljinska detekcija se sve češće koristi kao važan izvor za kartiranje, u geologiji učestvuje pri utvrđivanju geološke građe terena, u poljoprivredi pri proučavanju pedološkog sloja i različitih kultura, u šumarstvu u oblasti izučavanja vegetacionog pokrivača, u hidrologiji praćenja stanja voda, itd. Tu su i najnovije oblasti primene, poput praćenja i predviđanja elementarnih nepogoda i prirodnih katastrofa usled pomeranja tla, zaštita životne sredine i dr. Takođe, sistem daljinske detekcije ima dugu tradiciju u vojnim primenama, pre svega koristi se za izviđačke svrhe.

Stalni razvoj informacionih tehnologija omogućio je da daljinska detekcija u kombinaciji sa GIS-om i njegovim aplikacijama pruža korisne informacije širokom krugu korisnika. Geodetska nauka je posebno zainteresovana za određivanje pozicija objekata na terenu koje se dobijaju daljinskom detekcijom terena. U poslednje vreme na tržištu postoje satelitski snimci čije su prostorne rezolucije $i$ ispod $1 \mathrm{~m}$, na osnovu kojih se sigurno dolazi do kvalitetnog geodetskog proizvoda (numerički podatak, snimak, karta ...) sa neophodnom položajnom tačnošću.

Senzorski sistemi sa veličinom piksela od $6 \mathrm{~m}$ i manjom realno su upotrebljivi za izradu topografskih karata razmere 1: 50000 (TK 50) ili za dopunu TK 25. Ukoliko se radi o sistemima sa rezolucijom snimanja terena od $1 \mathrm{~m}$ i boljom, moguće je proizvesti karte razmere 1: 10000 , odnosno vršiti dopunu sadržaja karata razmera 1: 5000.

Međutim, sa aspekta položajne tačnosti moguće je koristiti i nešto lošije rezolucije, mada je tada smanjena moć interpretacije sadržaja. Odnos veličine piksela na snimku (PR) i odgovarajućeg faktora razmere karte ili plana (r) može se predstaviti izrazom $\mathrm{r}=\mathrm{PR} / 0,05 \mathrm{~mm}-$ $0,1 \mathrm{~mm}$, na osnovu kojeg se vrši izbor senzorskog sistema za potrebe izrade određenih topografskih karata i planova [2].

\section{Elementi daljinske detekcije}

Iz razmatranja principa proizilazi da $\mathrm{u}$ procesu daljinske detekcije učestvuje osam elemenata: objekat, elektromagnetna energija, senzor, platforma, snimak, analiza, interpretacija i informacija (podatak). Svaki od njih ima svoje specifičnosti.

\section{Predmet istraživanja-objekat}

Objekat, odnosno predmet istraživanja, u daljinskoj detekciji je Zemlja sa svim svojim komponentama (slika 3), mada taj termin može podrazumevati i deo kosmosa. U užem smislu reči, objekat predstavlja deo Zemljine površine za koji se traže informacije, koje se mogu dobiti pomoću daljinske detekcije. 


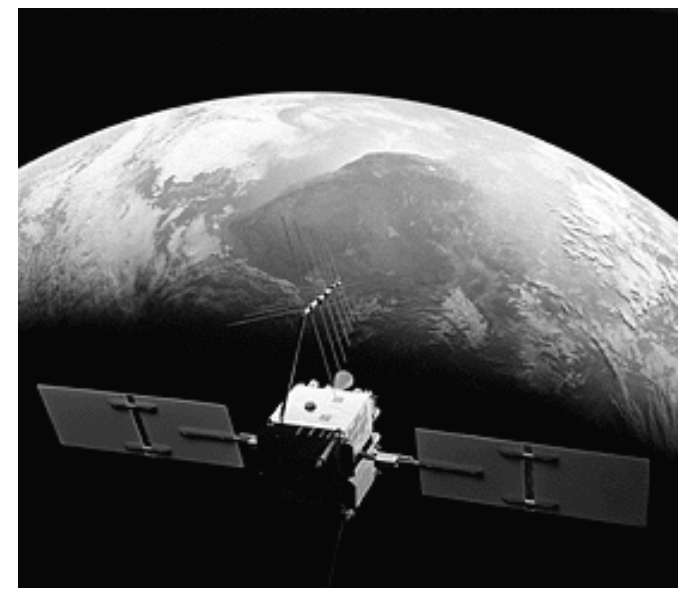

Sl. 3 - Predmet istraživanja daljinske detekcije [6]

Savremena kartografija koristi daljinsku detekciju kao bitan izvor podataka za ažuriranje i dopunu topografskih i svih ostalih vrsta karata.

Može se zaključiti da različite nauke i naučne discipline definišu posebni predmet istraživanja i prilagođavaju ga svojim potrebama.

\section{Elektromagnetna energija}

Svako telo na Zemljinoj površini usled Sunčevog zračenja poseduje energiju određene frekvencije i talasne dužine i sposobno je da emituje energiju dela elektromagnetnog spektra. Sva tela sastavljena su od određenih čestica materije koje poseduju odgovarajuće naelektrisanje. Ove čestice menjaju prostor oko sebe i stvaraju električno polje. Polje deluje silom na svako naelektrisanje koje se nalazi u njemu.

Naelektrisane čestice u pokretu čine električnu struju, koja izaziva dalje promene okolnog prostora i stvara magnetno polje. Magnetno polje, takođe, deluje silom na svaku naelektrisanu česticu u pokretu i tako naizmenično električno polje stvara magnetno i magnetno stvara električno polje. Elekromagnetna energija tako nastaje kao rezultat interakcije električnog i magnetnog polja i širi se kroz prostor zračenjem, i za nju važi opšti zakon talasnog kretanja (slika 4).

Opšti zakon talasnog kretanja glasi:

$$
C=\lambda \cdot f
$$

gde su:

$\lambda$ - talasna dužina (rastojanje između dva maksimuma i dva minimuma talasa), $\mathrm{f}$ - frekvencija (učestalost talasa ili broj celih talasa u sekundi),

$\mathrm{C}$ - brzina svetlosti.

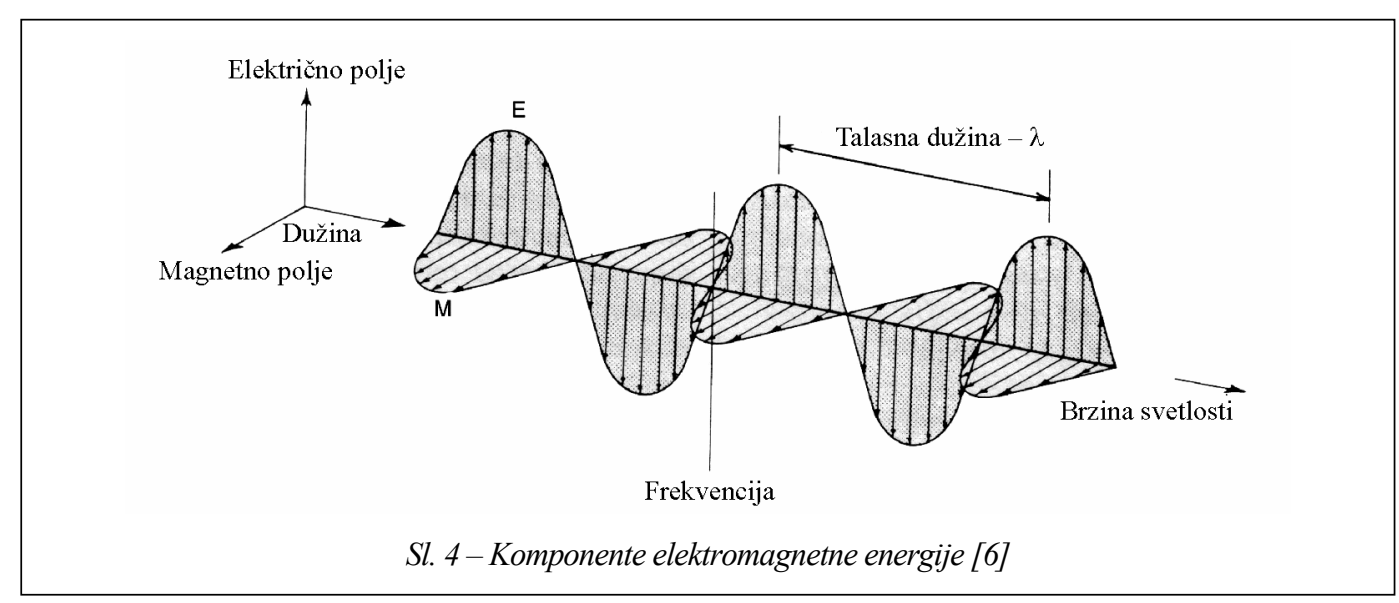




\section{Spektar elektromagnetnog zračenja}

Sve vrste zračenja predstavljaju spektar elektromagnetne energije, koja može da se podeli na oblasti relativno sličnih karakteristika [4]. Istorodne oblasti sastavljene su od više spektralnih linija, koje se sastoje od: područja $\gamma$ i x zraka; ultraljubičastog zračenja; područja vidljivog dela spektra; područja infracrvenog zračenja; mikrotalasnog i radio-talasnog područja.

Spektar EM energije deli se na više područja sličnih karakteristika. U tabeli 1 prikazani su delovi spektra EM zračenja sa odgovarajućim vrednostima talasnih dužina $(\lambda)$.

Spektar EM zračenja [4]

\begin{tabular}{|c|c|c|}
\hline \multicolumn{2}{|c|}{ Deo spektra } & $\lambda(\mu \mathrm{m})$ \\
\hline \multicolumn{2}{|c|}{$\gamma$ i $\chi$ zraci } & $<0,01$ \\
\hline \multirow{3}{*}{ Ultraljubičasti } & Daleki & $0,01-0,2$ \\
\cline { 2 - 3 } & Srednji & $0,2-0,3$ \\
\cline { 2 - 3 } & Bliski & $0,3-0,4$ \\
\hline \multicolumn{2}{|c|}{ Vidljivi deo } & $0,4-0,7$ \\
\hline \multirow{2}{*}{ Infracrvena } & Bliski & $0,7-1,5$ \\
\cline { 2 - 3 } & Srednji & $1,5-5,6$ \\
\cline { 2 - 3 } & Daleki & $5,6-1000$ \\
\hline \multicolumn{2}{|c|}{ Mikrotalasi } & $>1000$ \\
\hline
\end{tabular}

Zraci iz područja $\gamma i \chi$ zračenja imaju malu prodornost kroz atmosferu, pa su neupotrebljivi za daljinsku detekciju terena. Primenjuju se u fizici i medicini.
Ultraljubičasto zračenje (UV - ultravioletno), koje je otkrio Riter 1801. godine, čini $10 \%$ od ukupne svetlosne energije koja dospe na Zemljinu površinu. Talasne dužine UV zraka su male i kreću se od 0,1 do 0,4 $\mu \mathrm{m}$. Prodornost UV zraka iz dalekog i srednjeg dela UV područja kroz atmosferu praktično ne postoji, pa su oni u potpunosti neupotrebljivi u daljinskoj detekciji. U bliskom delu prodornost se povećava, ali su do sada obavljena ispitivanja imala prvenstveno eksperimentalni značaj.

Vidljivo područje spektra elektromagnetne energije obuhvata zračenja talasnih dužina od 0,4 do $0,7 \mu \mathrm{m}$. Njegove granice postavljene su prema osetljivosti ljudskog oka. Čovek registruje zračenje energije u vidljivom području kao tzv. „belu svetlost“. Prema talasnoj dužini u vidljivom delu spektra razlikuje se, međutim, više boja - od ljubičaste sa najkraćom $(0,4-0,044 \mu \mathrm{m})$, preko plave, zelene, žute i narandžaste, do crvene sa najvećom talasnom dužinom $(0,62-0,7 \mu \mathrm{m})$. Ove boje mogu se grupisati u tri osnovne: plavu $(0,4-0,5 \mu \mathrm{m})$, zelenu $(0,5-0,6$ $\mu \mathrm{m})$ i crvenu $(0,6-0,7 \mu \mathrm{m})$, kao što se vidi na slici 5 .

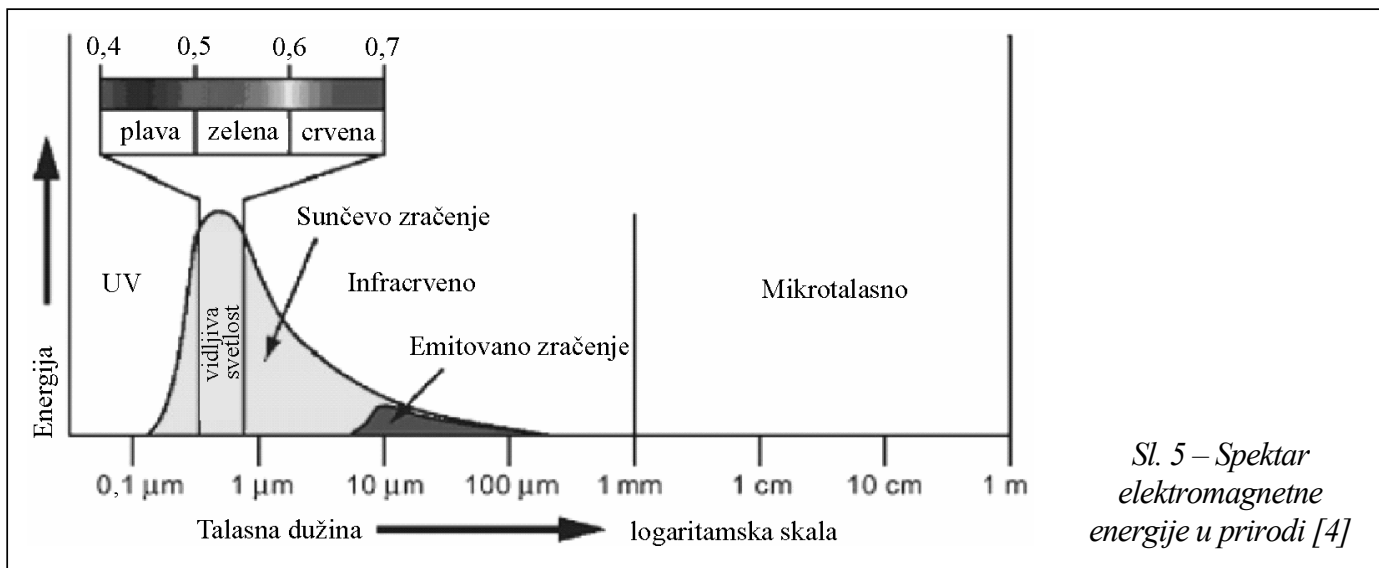


Osnovni izvor elektromagnetne energije vidljivih zraka je Sunce. Njihova prodornost kroz atmosferu je izuzetno visoka. Vidljivi deo predstavlja najviše i najčešće korišćeno spektralno područje u daljinskoj detekciji.

Infracrveno područje, označeno kao IC područje (standardna oznaka: IR - infra red), obuhvata vrlo širok spektar zračenja, čije talasne dužine variraju u rasponu od 0,7 do $1000 \mu \mathrm{m}$. U okviru njega razlikuju se:

- blisko infracrveno zračenje, sa talasnim dužinama između $0,7 \mu \mathrm{m}$ do $1,5 \mu \mathrm{m}$;

- srednje infracrveno zračenje, deo sa dužinama od 1,5 $\mu \mathrm{m}$ do $5,6 \mu \mathrm{m}$;

- daleko infracrveno zračenje talasnih dužina od 5,6 $\mu \mathrm{m}$ do $1000 \mu \mathrm{m}$.

U odnosu na izvor zračenja može se detektovati: emitovano (termalno) i reflektovano infracrveno zračenje. Reflektovano IC zračenje nastaje kao posledica Sunčevog zračenja i odbijanja od površine Zemlje ili od posmatranog objekta. Od ukupne Sunčeve energije 40\% čini IC zračenje.

Talasne dužine reflektovanog zračenja kreću se u rasponu od $0,7 \mu \mathrm{m}$ do 3 $\mu \mathrm{m}$. Emitovano IC zračenje predstavlja, prvenstveno, energiju emitovanu sa površine Zemlje u obliku toplote, pa se zbog toga naziva još i toplotno (termalno) IC zračenje. Emitovani deo IC zračenja obuhvata talasne dužine od $0,3 \mu \mathrm{m}$ do 1000 $\mu \mathrm{m}$. Prodornost reflektovanog zračenja je visoka u atmosferi, dok je kod emitovanih prodornost velika samo pri zračenju dužine do $14 \mu \mathrm{m}$.

Za daljinsku detekciju IC zračenje ima veliki značaj, a naročito sopstveno zračenje tela koje zavisi od sastava tog tela, te na taj način određuje njegova svojstva. Nijanse infracrvene boje su dobar pokazatelj temperaturnih razlika objekta na Zemljinoj površini.

Nijansa određene boje ukazuje na to da se radi o promeni temperature vode (otpadne i komunalne vode), promeni vegetacione strukture (zdrava i bolesna šuma) i slično. Zelena najviše, a crvena najmanje odbija ove zrake, pa se zbog toga naročito dobro može prikazati vegetacija, zbog reagovanja hlorofila na infracrvene zrake. Panhromatska fotografija je pogodna za analizu urbanog dela i stenovite podloge. Kod IC snimaka vode su prikazane tamnom nijansom, a kod panhromatske svetlom. Kod panhromatske fotografije trava je tamnijih boja, a kod IC fotografije svetlijih nijansi.

Snimci dobijeni uz pomoć IC zračenja primenjuju se u geologiji, geomorfologiji, pri proučavanju vulkana, lednika, u poljoprivredi, urbanizmu, itd. Fotografije ove vrste mogu se dobijati i noću, pa se zbog toga primenjuju u vojne svrhe. IC zraci probijaju se kroz maglu, izmaglicu, dim i slično.

Mikrotalasno područje obuhvata zračenja velikih talasnih dužina $i$ to od $1000 \mu \mathrm{m}-1000000 \mu \mathrm{m}(1 \mathrm{~mm}-1 \mathrm{~m})$. Ovo je područje EM spektra sa najvećim talasnim dužinama koje se koristi u daljinskoj detekciji. Mikrotalase može emitovati površina Zemlje (prirodnim putem) ili čovek (veštačkim putem). Kroz atmosferu mikrotalasni zraci prodiru velikom brzinom, a prodiru i kroz maglu, oblake, krošnje drveća, pa čak i kroz plitke naslage na površini terena, kao što su peskovi i aluvijalni sedimen- 
ti. Ovaj vid zračenja svakodnevno nalazi sve veću primenu u daljinskoj detekciji, kao i kod svih izviđanja i snimanja za vojne potrebe.

Radio-talasi predstavljaju zračenje sa najvećim talasnim dužinama, preko $1000000 \mu \mathrm{m}$ (preko $1 \mathrm{~m}$ ). Radio-talasi su veštačkog porekla. Koriste se u telekomunikacijama i nemaju veću primenu u daljinskoj detekciji.

Glavni emiteri EM zračenja su Sunce, površina Zemlje sa objektima na njoj i veštački izvori koje stvara čovek. Sunce je najdominantniji emiter, ali se samo deo spektra probije kroz atmosferu, odbije od površine Zemlje i dođe do senzora, jer količina energije Sunca nije ravnomerno raspoređena po spektralnim područjima. Najveći procenat energije je u vidljivom delu spektra, zatim u IR delu, ultraljubičastom, a zanemarljiv je u području mikrotalasa, radio-talasa i $\gamma$ i $\chi$ zračenja. Veštački izvori elektromagnetne energije su raznovrsni i emituju zračenja različitih talasnih dužina. U tabeli 2 prikazani su samo neki od ovih izvora.

Tabela 2

Izvori elektromagnetne energije [4]

\begin{tabular}{|c|c|}
\hline I z v o r & Vrsta zračenja \\
\hline $\begin{array}{c}\text { Skener sa pozitronskom } \\
\text { emisijom }\end{array}$ & $\gamma$-zraci \\
\hline Rendgenska cev & h-zraci \\
\hline Ultraljubičasta lampa & UV zraci \\
\hline Elektronski fleš fotoaparat & vidljivi zraci \\
\hline Laser & vidljivi zraci \\
\hline $\begin{array}{c}\text { Motor sa unutrašnjim } \\
\text { sagorevanjem }\end{array}$ & IC zraci \\
\hline Infracrvena lampa & IC zraci \\
\hline Mikropećnica & mikrotalasi \\
\hline Radar & mikrotalasi \\
\hline UHV TV odašiljač & mikrotalasi \\
\hline UHV TV odašiljač & radio-talasi \\
\hline
\end{tabular}

Uzajamni odnos između vrednosti talasne dužine u odnosu na objekte u prirodi, elektromagnetnog zračenja, izvora zračenja i frekvencije talasa prikazan je na slici 6.

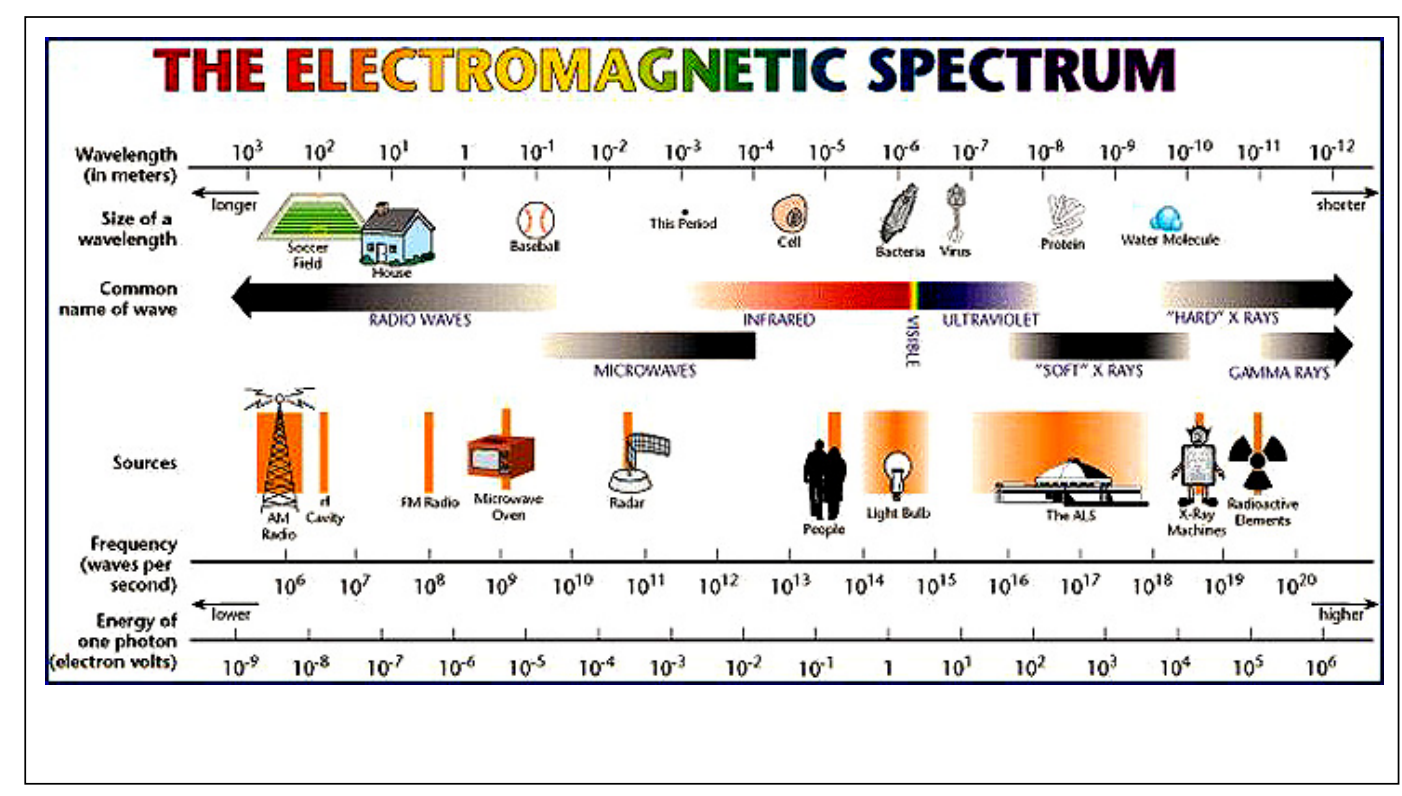




\section{Platforma}

Platforma je pokretni nosač senzora, koji treba da omogući registraciju elektromagnetne energije na većoj površini terena. Ona može da se kreće po površini zemlje (terestrička platforma), u vazdušnom prostoru (aeroplatforma) i u kosmosu (kosmička platforma) - slika 7.

U svim slučajevima platforma treba da obezbedi sistematsko snimanje. Da bi ovaj zahtev bio ispunjen pravci kretanja platforme moraju biti unapred utvrđeni i prostorno definisani. Tokom kretanja mora neprekidno da postoji mogućnost određivanja njenog tačnog položaja. Dobar kvalitet snimaka podrazumeva visoku stabilnost platforme, odnosno senzora pri kretanju.

Terestričke platforme mogu se kretati po kopnu ili vodi, te se u te svrhe koriste vozila ili plovila, posebno opremljeni automobili, odnosno brodovi.

Poseban vid terestričkog fotografskog snimanja je senzor, odnosno fotokamera kombinovana sa teodolitom. Ovako nastao instrument naziva se fototeodolit. Platformu senzora čini stativ koji se posle svakog načinjenog snimka pomera sa jedne stajne tačke na drugu. Na taj način pokrivena je jedna traka terena, obično nepristupačna kanjonska strana, ili slično. Savremena daljinska detekcija dosta koristi ove platforme i senzore, posebno pri inženjersko-geološkim i strukturnim istraživanjima.

Aerofoto snimanje izvodi se pomoću letelica - balona, helikoptera i aviona. Aero platforme nalaze se u vazdušnom prostoru na određenim visinama. Kao i kod terestričke platforme, na početku se utvrđuje pravac kretanja platforme, kako bi mogla da se izvode sistematska snimanja.

Sa platformi iz vazdušnog prostora obavljaju se snimanja:

- visoko aerofoto snimanje. Izvodi se uređajem za snimanje smeštenim na centralni deo specijalnog aviona najveće brzine (spejs šatl);

- aerofoto snimanje srednjih visina. Za platformu koristi avionske letelice srednjih brzina (mlazni avioni), a uređaj za snimanje je, takođe, na donjem delu letelice;

- aerofoto snimanje malih visina. Izvodi se do par kilometara, a za platfor$\mathrm{mu}$ koristi najjednostavnije avionske le-

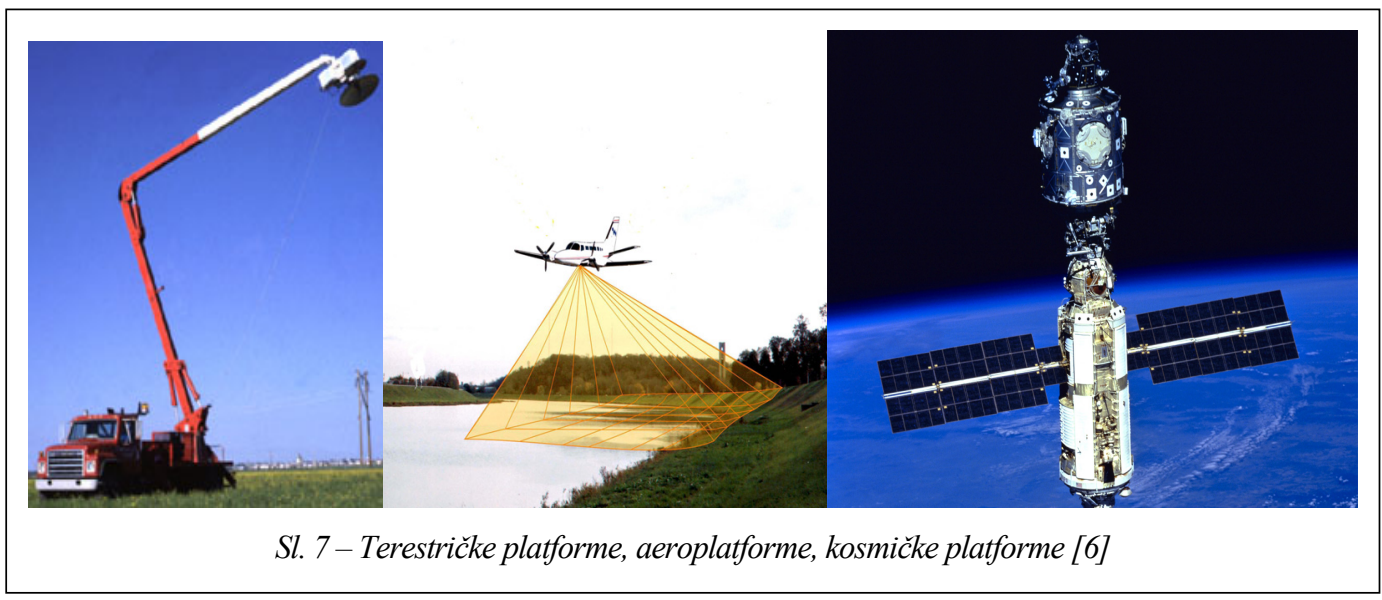


telice, balone i helikoptere. Uređaj za snimanje može, a ne mora da bude fiksiran za letelicu.

Kao kosmičke platforme koriste se veštački Zemljini sateliti i kosmički brodovi. Sateliti imaju fiksnu putanju kretanja i rade potpuno automatizovano, bez ljudske posade. Putanja kretanja kosmičkih brodova je promenljiva, dirigovana komandama posade. Ukoliko je brod automatizovan, bez ljudske posade, njegovim kretanjem upravlja se radio-vezom iz komandnog centra sa Zemlje. Za sistematska snimanja iz kosmosa redovno se koristi više različitih senzora.

U praksi je veoma teško održati satelit na pravilnoj orbiti (putanji). Neki sateliti, pre svega vojni, da bi mogli snimati u krupnijoj razmeri, ne samo da su bliži Zemlji (od 160 do $250 \mathrm{~km}$ ), već se kreću po prilično izduženim eliptičnim putanjama, tako da se iznad zainteresovanog područja nađu na što manjim visinama. Takvi sateliti obično imaju male „sisteme“ kojima vrše korekciju putanje i time produžavaju vreme svog trajanja i operativnog rada. Za potrebe daljinskih istraživanja najbolje je kombinovati snimke Zemljine površi dobijene sa različitih platformi.

\section{Senzori}

Senzori su uređaji za uočavanje, registrovanje i merenje zračenja elektromagnetne energije, bilo da se radi o emitovanoj ili reflektovanoj energiji. Najstariji senzor je ljudsko oko i ono registruje samo vidljivi deo spektra. Senzori su i skeneri, radari, kamere i slični uređaji.

Postoje mnoge podele postojećih senzora, a osnovna se zasniva na poreklu registrovane energije, prema kojoj razlikujemo pasivne i aktivne senzore.

Prema konstruktivnim karakteristikama i načinu rada senzori se mogu svrstati u tri osnovne grupe: foto-optički, elektro-optički i mikrotalasni senzori.

\section{Foto-optički senzori}

Foto-optički sistemi (poznatiji kao foto-kamere) imaju najdužu primenu u daljinskoj detekciji (fotogrametriji).

Princip fotogrametrijskog snimanja zasnovan je na skoro trenutnom nastajanju snimka na osnovu centralne projekcije prostora. Na slici 8 prikazan je koncept aerofotogrametrijskog snimanja, gde se teren (A), nakon prolaska svetlosnog signala kroz objektiv (B), registruje $u$ fokusnoj ravni (C) uz pomoć pasivnog senzora (foto-emulzije). Foto-emulzije su osetljive na svetlost talasnih dužina od $0,3 \mu \mathrm{m}$ do $0,9 \mu \mathrm{m}$, čime se pokriva deo ultraljubičastog spektra, celo vidljivo područje i deo infracrvenog spektra.

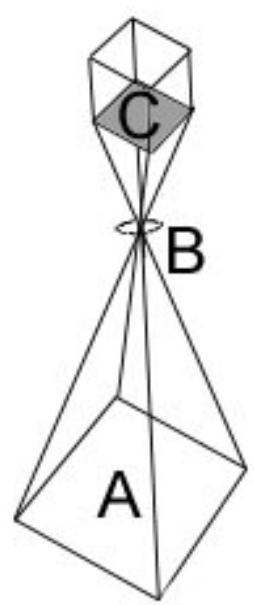

Sl. 8 - Koncept aerofotogrametrijskog snimanja [1] 


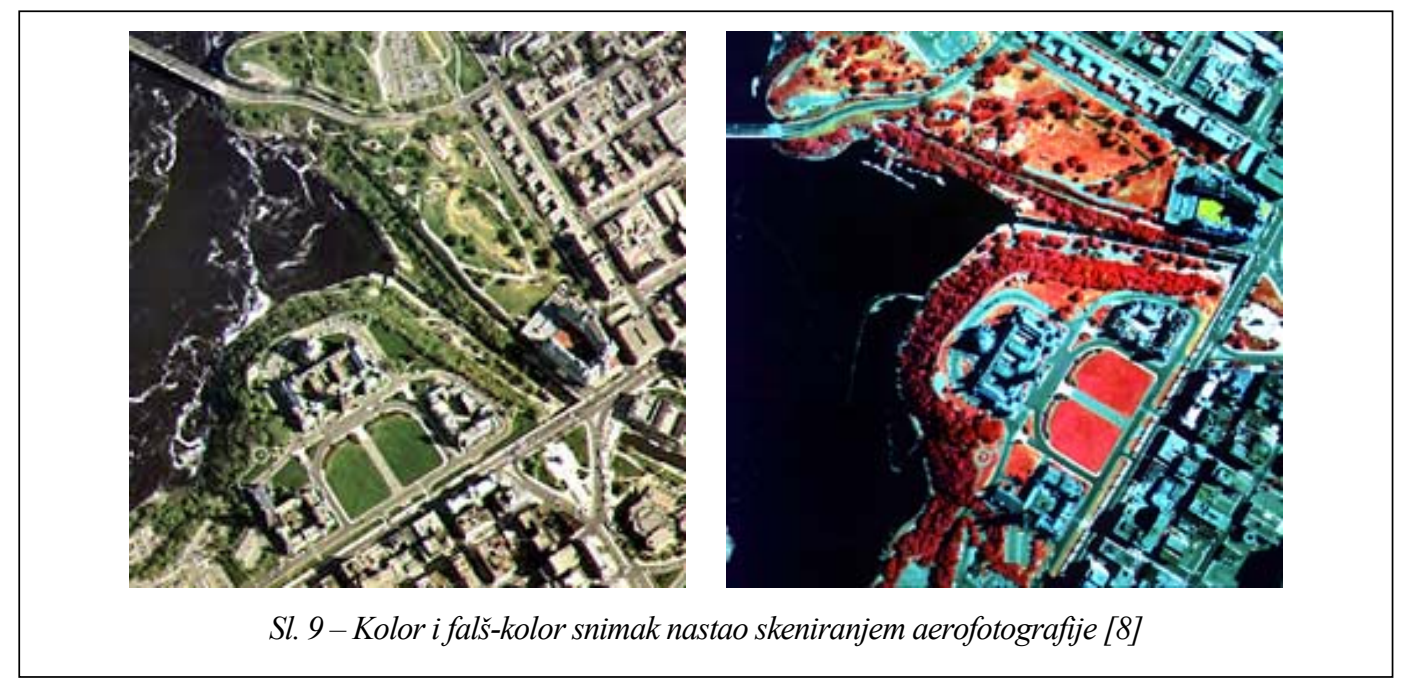

Panhromatski filmovi detektuju UV i vidljivo područje spektra. To su crnobele fotografije, koje su najčešće primenjivane $\mathrm{u}$ aerofotogrametriji. Infracrvene crnobele emulzije, pored bele svetlosti detektuju i infracrveni deo do $0,9 \mu \mathrm{m}$. Boje na snimku nemaju prirodne tonove, ali je moguće, zahvaljujući termalnom zračenju i IC zracima, prikupiti dodatne informacije o vrsti objekata na terenu, što posebno važi za vrstu vegetacionog pokrivača i površine bogate vodom.

Kolor filmovi imaju tri nivoa emulzije osetljivih na tri osnovne boje, te za čoveka izgledaju normalno. Kolor infracrvene emulzije imaju takođe tri nivoa filma koji su osetljivi na zelenu, crvenu i blisku infracrvenu radijaciju, a na fotografiji se prikazuju kao plava, zelena i crvena, respektivno. Falš-kolor fotografije prikazuju infracrvenu boju crvenom, crvenu kao zelenu, i zelenu kao plavu, što čoveku takođe daje „falš“ prezentaciju stvarnosti. Na slici 9 prikazan je isti teren snimljen u kolor i falš-kolor tehnici.

Fotogrametrijska kamera može biti postavljena na različitim platformama poput onih na Zemlji (terestričkih), na avionu, helikopteru ili satelitu. Najveći značaj imaju i najčešće se primenjuju aerofotogrametrijske kamere.

\section{Elektrooptički senzori}

Uređaji koji registruju i pretvaraju elektromagnetnu energiju (emitovanu i reflektovanu) u električni impuls nazivaju se elektrooptički senzori (elektrooptički sistemi). Impulsi dalje stvaraju prepoznatljivu sliku iz prirode. Među elektrooptičkim senzorima razlikuju se video i televizijske kamere, vidikon kamere i skeneri. Fotografske, video, televizijske i vidikon kamere registruju EM zračenje trenutno za celo posmatrano područje.

Skeneri se najviše primenjuju u daljinskom snimanju Zemlje, a pomoću njih snimak nastaje skeniranjem linija, sukcesivno. Prema načinu na koji snimak nastaje skeniranjem, postoje različite konstrukcije skenera. Na slici 10 prikazani su najčešće primenjivani, poprečni (along track) i uzdužni skeneri (across track). 


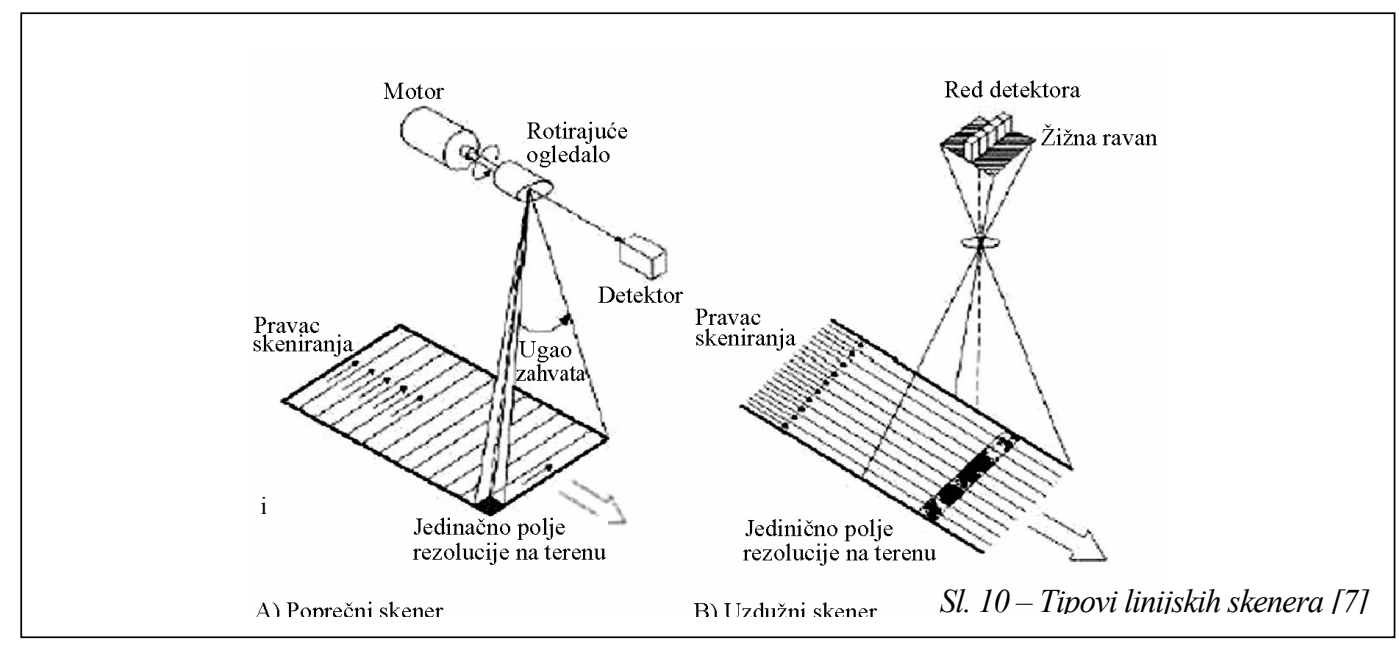

Elektrooptički sistem koji posebno registruje elektromagnetnu energiju različitih talasnih dužina, tj. zračenja različitih spektralnih područja, naziva se multispektralni skener (slika 11).

Multispektralni skeneri novijih konstrukcija mogu registrovati i preko $10 \mathrm{ka}-$ nala. Svaki registrovani snimak u određenom kanalu predstavlja zasebnu crnobelu sliku snimljenog područja i naknadnim kombinovanjem mogu nastati kolor kompoziti. Raspon talasnih dužina koje registruju multispektralni skeneri kreće se od 0,3 do $1,4 \mu \mathrm{m}$.

Za daljinska istraživanja značajan je termalni infracrveni skener, koji pretvara infracrveno zračenje u električne impulse. Sastoji se od podloge, filma, magnetoskopske trake i računarskog diska (CD-a). Energija se prevodi u vidljivu sliku na isti način kao kod multispektralnog skenera.

Senzori iz grupe elektrooptičkih senzora imaju neke prednosti u odnosu na foto-optičke. Ovde se misli na znatno šire područje registrovanja spektralnih područja, energija se može zabeležiti na CD-u, pa se može računarski obraditi.

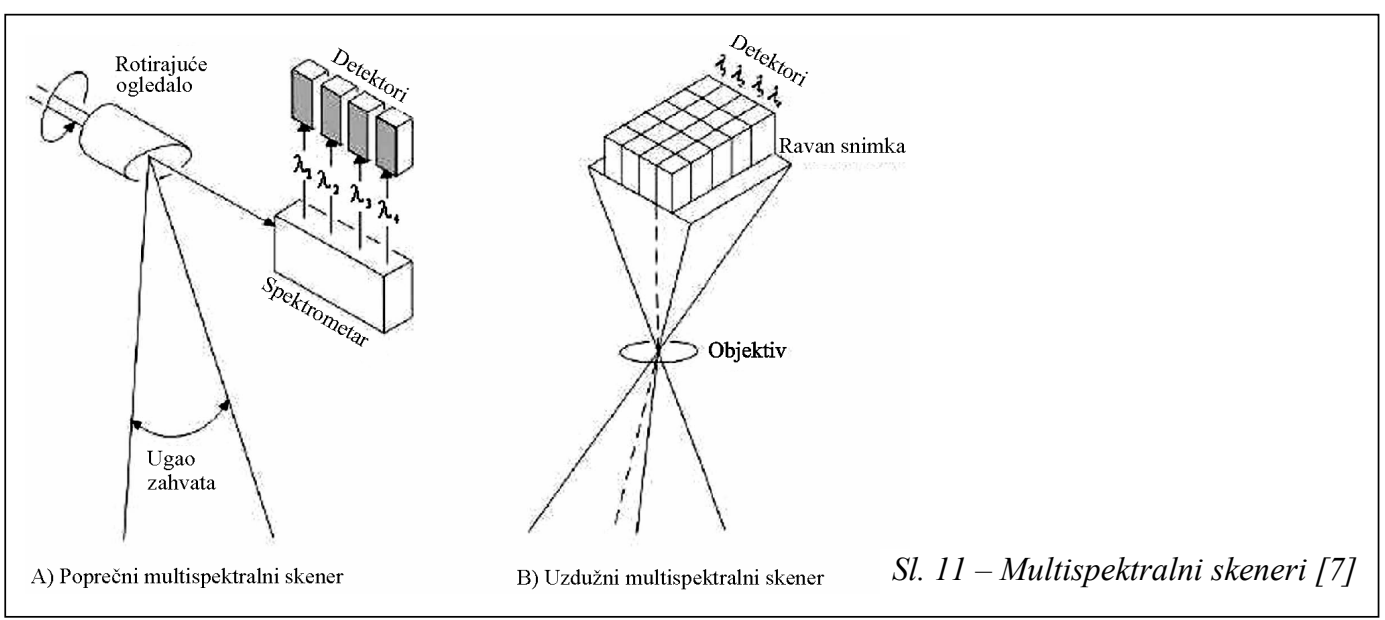


Zabeležena energija može se neposredno posmatrati i prenositi radio-vezom, što znači da su snimanja automatizovana, dugotrajna i da se mogu vršiti bez direktnog učešća čoveka.

Najveću primenu ovi senzori imaju u geodeziji i kartografiji za kartiranje, u geologiji sa akcentom na utvrđivanje geološke građe terena, u poljoprivredi na pedološki sloj i različite kulture, u šumarstvu na vegetacioni pokrivač, u hidrologiji na vode, itd. Tu su još i neke specifične primene poput praćenja i predviđanja elementarnih nepogoda i prirodnih katastrofa usled pomeranja tla, zaštita životne sredine i druge. Takođe, važno je istaći da sistem daljinske detekcije ima dugu tradiciju u vojnim primenama, pre svega za izviđačke svrhe. Početak razvoja i primene daljinske detekcije proizašao je iz zahteva armija ekonomski najrazvijenijih zemalja za praćenje stanja svih drugih zemalja.

\section{Mikrotalasni senzori}

Senzori iz grupe mikrotalasnih mogu samo beležiti energiju objekta posmatranja (pasivni) i mogu proizvoditi, slati i registrovati elektroenergiju (aktivni). Elektromagnetna energija koja se emituje može biti prirodna - emituje je objekat, ili veštačka - emitovana sa nekog veštačkog izvora, poslata objektu i reflektovana od njega.

Intenzitet prirodnog mikrotalasnog zračenja je izuzetno slab, pa se pasivni senzori ne koriste u daljinskoj detekciji. Osnovni aktivni senzor iz grupe mikrotalasnih sistema je radar. Naziv radar je akronim reči RAdio Detection And Ran- ging, što u slobodnom prevodu znači otkrivanje i merenje udaljenosti objekta radio-talasima. Radar se u daljinskoj detekciji može koristiti i danju i noću, jer kod njega proces detekcije zračenja ne zavisi od Sunčeve energije (slika 12). On proizvodi mikrotalasno zračenje, emituje to zračenje prema objektu i registruje odbijenu energiju kao signal nazvan eho. Intenzitet eha za jedan tip radara zavisi od osobina objekta. Mikrotalasi prodiru kroz oblake i maglu, koji drugim senzorima predstavljaju velike smetnje pri detekciji.

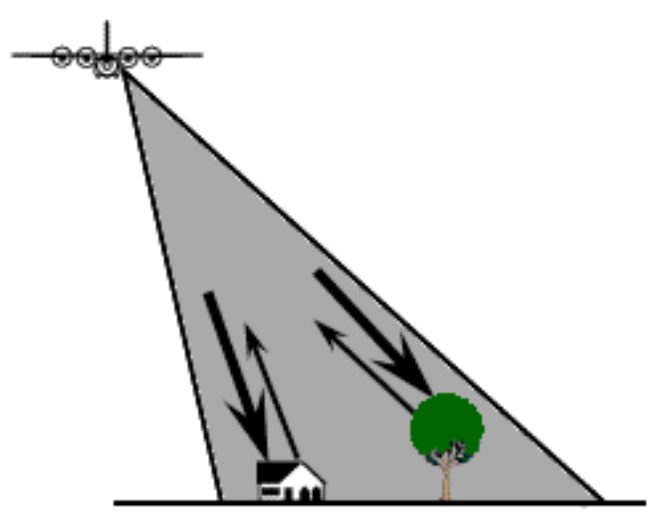

Sl. 12 - Radarsko snimanje terena [1]

Radar je najpogodniji za daljinska istraživanja, jer ne zavisi od vremenskih uslova. Radarsko snimanje može se izvoditi i danju i noću, zraci lako prolaze kroz oblake i maglu i sl. Uređaji se mogu podesiti tako da se registruju određeni zraci pod uglom, kako bi se iskazala svojstva određene pojave.

Daljinska detekcija koristi radar sa bočnim zahvatom, koji se javlja u dve varijante: kao radar sa realnom i kao radar sa sintetičkom aperturom. Apertura predstavlja otvor kroz koji senzor reflektuje ili prima elektromagnetnu energiju, a 
sastoji se i od antene, odašiljača i prijemnika. Radar sa bočnim zahvatom poznat je pod nazivom SLAR (Side Looking Airborne Radar), u slobodnom prevodu bočno usmereni radar za snimanja iz vazdušnog prostora. Ovaj naziv se sve češće zamenjuje kraćim nazivom SLR, od Side Looking Radar (bočno usmereni radar), pošto se ovaj senzor široko koristi i pri kosmičkim snimanjima.

Radar sa realnom aperturom, nazvan RAR (Real Aperture Radar), obuhvata već poznate elemente: antenu (koja služi za emitovanje i prijem energije), odašiljač, prijemnik, prekidač za promenu funkcije antene, katodnu cev za prikaz registrovanog reflektovanog zračenja i fotografski uređaj za trajno pohranjivanje ovog zračenja. Osnovno ograničenje RAR sistema jeste mala dužina antene, što uslovljava i nizak kvalitet snimka.

Radar sa sintetičkom aperturom poznat je pod imenom SAR (Synthetic Aperture Radar). Antena ovog senzora je veštački (sintetički) produžena, za šta je iskorišćeno kretanje letelice. Stvarna antena, npr. dužine 1-2 metra, postavljena na avionu, može proizvesti sintetičku antenu dužine i do 600 metara. Stvarna antena od 11 metara, postavljena na kosmičkoj letelici, može sintetizovati antenu efektivne dužine od 15 kilometara.

U daljinskoj detekciji koriste se sve vrste radara i sve vrste senzora. Najbolja je kombinacija svih sistema (senzora), zato što svaki pojedinačno ima određene nedostatke.

\section{Karakteristike senzora}

Bitne karakteristike senzora koje dolaze do izražaja u daljinskim istraživanjima su:
- prostorna rezolucija - najmanja jedinica zemljišta koja se na snimku može prepoznati (30x30 m, 5x5 m i sl.);

- spektralna rezolucija - određena širinom spektralnih kanala i brojem kanala koji stoje na raspolaganju, na primer, crnobela fotografija dobijena je $u$ jednom kanalu, a multispektralni skeneri daju proizvode sa više spektralnih kanala;

- radiometrijska rezolucija - ukupan broj sivih nijansi u jednom kanalu (najčešće 256 ili 64);

- vremenska rezolucija - period u kojem satelit prelazi isto područje (izraženo brojem dana);

- položajna tačnost - tačna lokacija u realnom prostoru;

- visinska tačnost - treća dimenzija objekta, pojave ili procesa;

- raspoznavanje objekta, pojave ili procesa-dešifrovanje objekta sa snimka.

\section{Prostorna rezolucija i veličina piksela}

Senzori koji obavljaju snimanja sa kosmičkih platformi zahvataju široko područje Zemljine površine, pa zato najčešće ne mogu prikazati sitnije detalje. $\mathrm{S}$ druge strane, senzori koji su na terestričkim ili aeroplatformama mogu prikazati mnoge detalje, ali zato zahvataju malu površinu. U tome je jedna od glavnih razlika daljinske detekcije i aerofotogrametrije.

Prostorna rezolucija predstavlja meru prostorne detaljnosti snimka, koja je u funkciji konstrukcije senzora $\mathrm{i}$ visine leta, tj. orbite platforme. Rezo- 
lucija se, najčešće, izražava kao veličina površine piksela na Zemlji. Da bi se neki objekat mogao prepoznati potrebno je da njegove dimenzije budu veće od veličine piksela. Međutim, i objekat koji je manji od piksela može biti detektovan, ako je mnogo svetliji ili tamniji od svoje okoline, jer će dominirati u sumi vrednosti energije koja je dospela do senzora za tu elementarnu površinu. Na taj način se otkriva da se tu nešto nalazi, iako se neće znati šta je to. Oblast koju je senzor zahvatio na površini Zemlje naziva se rezolucijska ćelija i određuje najveću prostornu rezoluciju snimka.

Postoji bitna razlika između piksela i prostorne rezolucije. Ako je prostorna rezolucija nekog sistema jedan metar, to znači da je veličina piksela na snimku 1x1 metar. U većini slučajeva su isti, ali je moguće prikazati snimak sa različitom veličinom piksela u odnosu na prostornu rezoluciju. U tabeli 3 date su vrednosti prostorne rezolucije nekih satelitskih misija.
Tabela 3

Prostorne rezolucije nekih satelitskih misija [4]

\begin{tabular}{|c|c|c|}
\hline Misija & $\begin{array}{c}\text { Panhromatski } \\
(\mathrm{m})\end{array}$ & $\begin{array}{c}\text { Multispektralni } \\
(\mathrm{m})\end{array}$ \\
\hline Landsat 7 ETM & 15 & 30 i 60 \\
\hline Spot 4 & 10 & 20 \\
\hline Spot 5 & 2,$5 ; 5$ i 10 & 20 \\
\hline IKONOS & 1 & 4 \\
\hline Radarsat II & 12,5 i 1000 & - \\
\hline Alos & 2,5 & 2,5 \\
\hline IRS-P5 & 2,5 & - \\
\hline
\end{tabular}

Često se koriste pojmovi „loša“ i „dobra“ rezolucija snimka. Pod lošom rezolucijom podrazumeva se takva prostorna rezolucija pomoću koje nije moguće videti sitnije detalje postojane u prirodi. Dobra rezolucija je takva da se na snimku mogu videti i sitnije pojave i oblici. Snimci koji se koriste u vojne svrhe imaju veoma visoku rezoluciju u odnosu na komercijalne, a sistemi pomoću kojih se oni dobijaju obično su pod određenim stepenom tajnosti.

Na slici 13 prikazan je snimak loše i dobre rezolucije. Snimci koji se koriste u vojne svrhe imaju visoku rezoluciju zbog
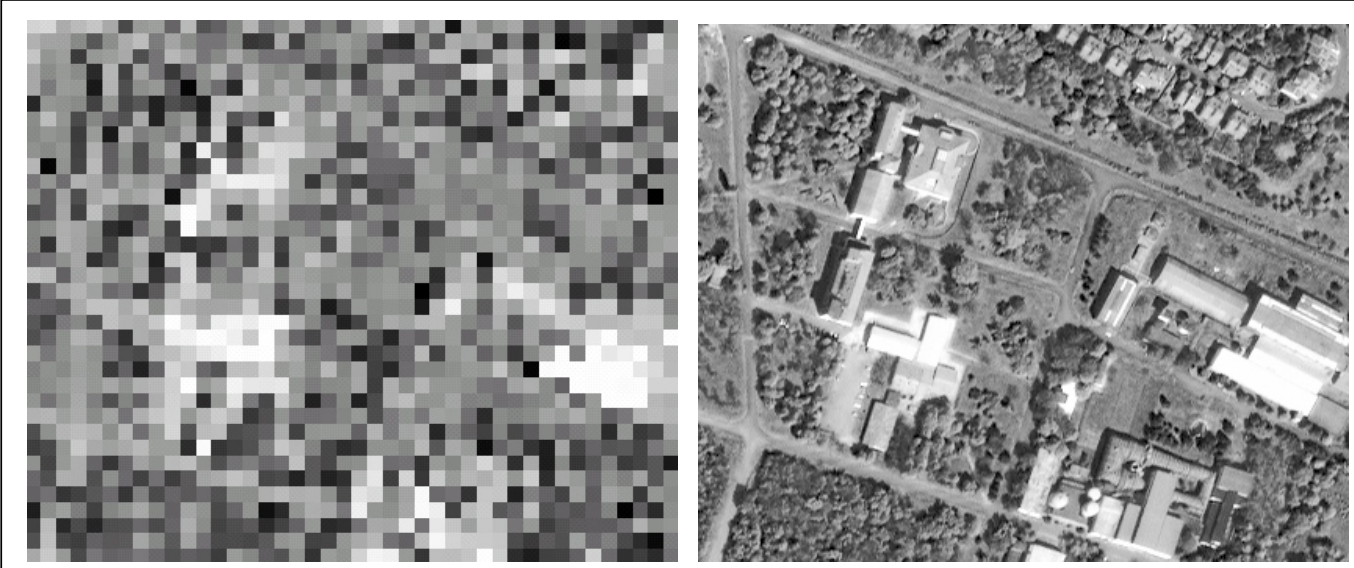

Sl. 13 - Snimak loše rezolucije (IKONOS - 10 m) i snimak dobre rezolucije (IKONOS - Im) [5] 
potrebe da se vidi što više detalja, dok se u daljinskoj detekciji koriste snimci od metarske rezolucije do snimaka sa kilometarskom rezolucijom. Dakle, što je obuhvaćena manja površina Zemlje, to je bolja rezolucija snimka.

\section{Spektralna rezolucija}

Spektralna rezolucija predstavlja blizinu i broj spektralnih kanala korišćenih u senzoru. Takođe, spektralna rezolucija može se opisati kao mogućnost senzora da registruje različite delove EM spektra, odnosno manje intervale talasnih dužina, kao i mogućnost razlikovanja bliskih intervala. Ona pokazuje koje delove spektra senzor pokriva i koliko kanala može registrovati. Kod klasifikacije je povoljnije da senzor ima spektralno uske kanale, ali istovremeno veliki broj kanala, kako bi bili zahvaćeni svi željeni delovi spektra. To je jednostavno prikazano na slici 14. Što je finija spektralna rezolucija, to je uži interval talasne dužine za određeni kanal.

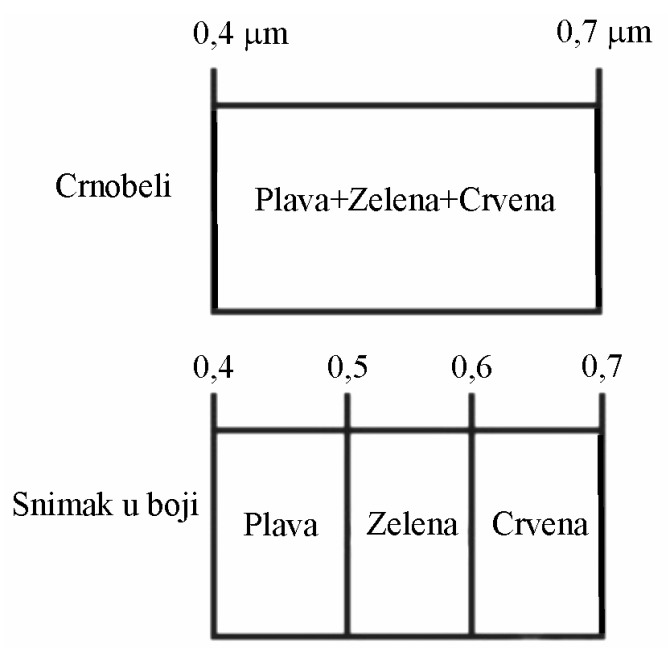

Sl. 14 - Spektralna rezolucija crnobelog i kolor snimka [4]

Crnobeli snimci registruju čitav interval zračenja vidljivog dela spektra $u$ samo jednom kanalu. Njihova spektralna rezolucija je veoma loša, zbog toga što različiti intervali talasnih dužina vidljivog dela spektra nisu pojedinačno registrovani, već je registrovana sva odbijena energija iz vidljivog dela spektra. Kolor snimci su, takođe, osetljivi samo na vidljivi deo spektra, ali je kod njih posebno registrovan deo zračenja talasnih dužina plave, zelene i crvene boje, pa time imaju i bolju spektralnu rezoluciju. U praksi se izraz visoka spektralna rezolucija koristi kod sistema sa većim brojem spektralnih kanala.

Da bi snimak imao što bolju spektralnu rezoluciju potrebni su senzori koji će registrovati zračenja iz različitog dela spektra, odnosno uske intervale talasnih dužina. O takvim senzorima je ranije bilo reči i oni se nazivaju multispektralni skeneri. Danas postoje i napredni multispektralni skeneri koji se nazivaju hiperspektralni skeneri. Oni registruju stotine uskih intervala talasnih dužina vidljivog dela, bliskog i srednjeg infracrvenog područja elektromagnetnog spektra.

\section{Radiometrijska rezolucija}

Signal koji dospeva do senzora je kontinualnog tipa, pa se mora kvantifikovati u obliku diskretnih vrednosti. Osetljivost snimka na količinu registrovane energije dobijene pomoću senzora određuje veličinu radiometrijske rezolucije, koja govori o mogućnosti da se prikaže što manja promena u energiji. Što je ova 
rezolucija senzora bolja, to je i registrovanje malih razlika u emitovanom ili odbijenom zračenju bolja, tj. moguće je prikazati manje promene EM energije.

Kao što je rečeno, snimak se sastoji od velikog broja piksela. Svaki piksel nosi određenu količinu informacija o delu terena koji je njime obuhvaćen. Količina informacija koju sadrži jedan piksel meri se brojem bitova koji taj piksel reprezentuje i naziva se dubina piksela. Jedan bit je binarna jedinica, „broj“ koji može da ima jednu od dve moguće vrednosti 0 ili 1, ili drugim rečima ,isključeno“ ili „uključeno“. Osnova za taj zapis je 2. Prikazuju se u ovom sistemu, jer je čitav računar zasnovan na binarnom sistemu brojeva. Bit je eksponent osnove, pa ako je snimak zapisan u 1 bitu to bi bilo $2^{1}=$ 2. To znači da bi emitovana ili reflektovana energija koja je registrovana bila prikazana samo u dve vrednosti. Ako je snimak u osmobitnom zapisu, onda bi to bilo $2^{8}=256$, što znači da će energija koja je registrovana biti prikazana u 256 vrednosti i to u nizu od 0 do 255 .

$\mathrm{Za}$ beleženje više nijansi sivog tona potrebno je povećati dubinu piksela. Najčešće korišćeni broj bitova za prikaz jednog piksela prikazan je u tabeli 4 .

Tabela 4 Standardni broj bitova za prikaz jednog piksela [7]

\begin{tabular}{|c|c|}
\hline Broj bita & Broj nijansi sivog tona \\
\hline 8 & $2^{8}=256$ \\
\hline 16 & $2^{16}=65536$ \\
\hline 24 & $2^{24}=16777216$ \\
\hline
\end{tabular}

Pri skeniranju analognog snimka u crvenom, zelenom i plavom delu spektra, umesto jedne, kao kod monohromatskog snimka, dobijaju se tri matrice, a isti piksel tri digitalne vrednosti. Istovremenim prikazom sve tri matrice, $\mathrm{tj}$. sve tri boje $\mathrm{u}$ intenzitetu koji determiniše nivo sivog tona za svaku od njih dati piksel dobija stvarnu boju. Osnovne boje prikazane su osmobitnim zapisom u 256 nijansi, čime se na izlazu dobija 2563, tj. više od 16 miliona boja u 24-bitnom zapisu. Danas je uobičajeno da se za zapis kolor snimka uzima 24-bitna ili još kvalitetnija dubina piksela, ali nije retkost da se i kolor snimak prikazuje osmobitnim zapisom. Prikaz crvenog, zelenog ili plavog tona istog piksela reguliše se preko kolor mape koja sadrži procedure za učitavanje svakog piksela kolor slike kroz tri podnivoa učitavanja svake boje u malim intervalima, da bi se na kraju ostvarilo kolor viđenje. Kolor mapa je u funkciji hardvera na kojem se vrši prikaz slike, kao što su monitor, ploter i drugo.

U tabeli 5 prikazan je primer šestobitnog zapisa gde je nivo sivog tona prikazan u 64 nijanse.

Tabela 5

Crnobela slika prikazana paletom od 0 do 64 nivoa sivog tona [7]

\begin{tabular}{|c||c||c||c||c||c||c||c||c|}
\hline 12 & 9 & 14 & 19 & 12 & 9 & 14 & 19 & 9 \\
\hline \hline 14 & 16 & 23 & 34 & 14 & 33 & 23 & 34 & 33 \\
\hline \hline 13 & 25 & 17 & 25 & 13 & 16 & 17 & 25 & 16 \\
\hline \hline 10 & 13 & 38 & 12 & 10 & 13 & 38 & 12 & 13 \\
\hline \hline 8 & 19 & 43 & 19 & 8 & 19 & 43 & 19 & 19 \\
\hline \hline 16 & 0 & 26 & 5 & 16 & 0 & 26 & 5 & 0 \\
\hline \hline 25 & 12 & 12 & 17 & 25 & 12 & 12 & 17 & 12 \\
\hline \hline 34 & 22 & 15 & 23 & 34 & 22 & 15 & 23 & 22 \\
\hline \hline 22 & 21 & 19 & 36 & 22 & 21 & 19 & 36 & 21 \\
\hline \hline
\end{tabular}




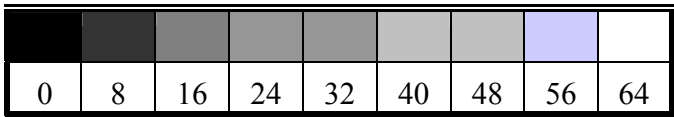

Vrsta zapisa determiniše broj mogućih vrednosti nivoa sivog tona (nijansi), što je u direktnoj vezi sa kvalitetom rasterske slike i vernošću zabeleženog elektromagnetnog odraza. Čovek je u mogućnosti da svojim okom razlikuje od 20 do 30 nijansi sivog tona. Razbijanje (diskretizacija) analognog snimka na mnoštvo malih ćelija (piksela) sa jednoznačno definisanim položajem i brojčano izraženom vrednošću nivoa sivog tona je prelomni momenat i uvod u digitalnu obradu snimaka. Digitalna obrada snimaka je, u krajnjoj liniji, rezultat primene saznanja koja je razvila teorija obrade signala i samim tim još jedan pokazatelj interdisciplinarnosti daljinske detekcije, kako u njenoj teoriji, tako i u praksi. Jedini nedostatak snimaka koji imaju visoku radiometrijsku rezoluciju je količina memorije koju oni zauzimaju. Što je radiometrijska rezolucija viša, to snimak zauzima više memorije.

\section{Vremenska rezolucija}

Promene na Zemljinoj površi dešavaju se u intervalima od nekoliko godina do nekoliko vekova, ali se i menjaju iz dana u dan, pa je potrebno često i permanento opažanje iz svemira. Ponovno snimanje istog područja posle nekog vremena pruža mogućnost različitih analiza promena nastalih uticajem čoveka ili prirode. Vremenska rezolucija odnosi se na vreme, odnosno označava koliko često satelit može snimiti isto područje [3]. Izražava se periodom između dva uzastopna snimanja istog područja.

\section{Snimci}

Pod snimkom se podrazumeva svaki zapis zračenja elektromagnetne energije. Drugim rečima, zabeležen elektromagnetni spektar ili zabeleženo zračenje koje nosi elektromagnetna energija zove se snimak. On nije fotografija; njegovo značenje je znatno kompleksnije i šire. Fotografija je samo jedna vrsta snimka. Danas se snimak koristi u mnogim oblastima ljudske delatnosti, kako za analitičke, tako i za merne svrhe.

$\mathrm{Na}$ osnovu snimaka dobijaju se pouzdane informacije o promenama na zemljištu i objektima na njemu. Snimak predstavlja značajan izvor informacija posmatranog
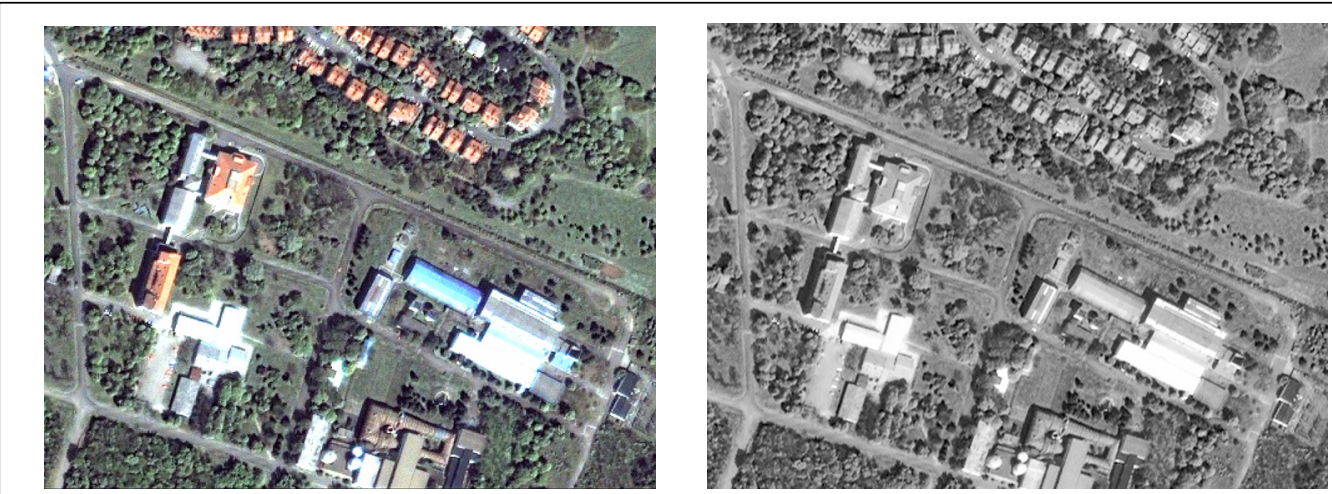

Sl. 15 - Satelitski snimci, kolor i crnobeli [5] 


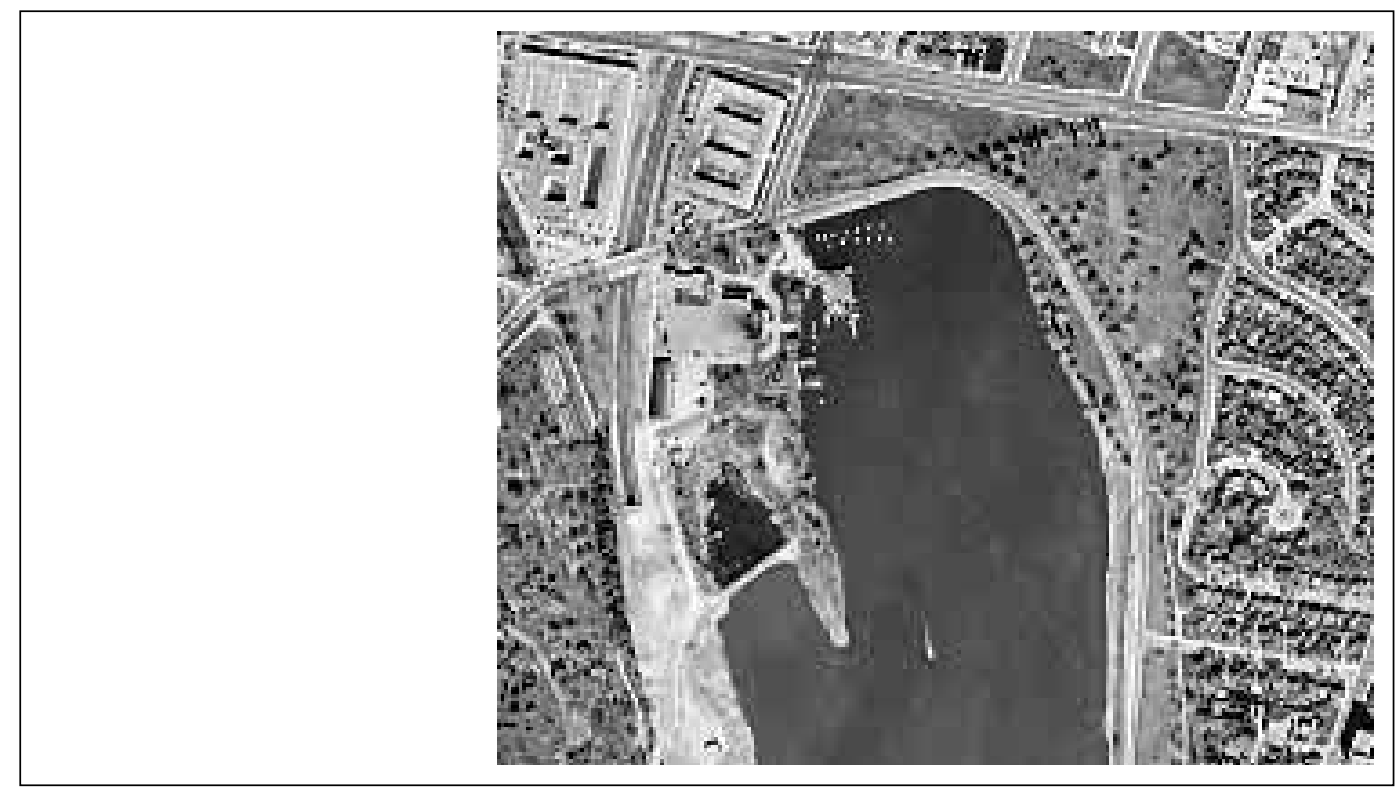

Sl. 16 - Zračenje EM spektra registrovano kao fotografija [1]

pojave ili procesa. On nije upotrebljiv ako samo registruje spektar elektromagnetne energije, već je zbog toga neophodno da prevede tu energiju u vidljivu i jasnu sliku. Kod obične fotografije on se odmah javlja kao vidljiva slika, ali kod ostalih sistema to nije slučaj (radar, skener). Kod radara ili skenera on se obrađuje putem računara $i$ prikazuje na ekranu, zatim se može štampati ili preneti na filmsku traku i dalje obrađivati. Vidljiva slika snimka može biti kolor, crnobela, lažni kolor, kolor kompozit i dr. Kolor kompoziti su proizvodi dobijeni kombinovanjem monohromatskih snimaka iz različitih senzora. U pojedinim oblastima istraživanja koristi se lažni film, kako bi se lakše otkrile određene pojave na terenu. U daljinskoj detekciji naročitu primenu našli su u otkrivanju vegetacionog pokrivača (analiza vegetacije). $U$ određenim istraživanjima kombinuju se snimci različitih boja.
U praksi se javlja više vrsta snimaka. Za potrebe daljinskih istraživanja koriste se skenogrami - ukoliko je snimanje izvršeno skenerskim senzorom, fotogrami - ukoliko je snimanje izvršeno fotografskim aparatom sa Zemlje i radarski snimak - ukoliko je senzor radar. Fotografski snimci često se digitalizuju i računarski obrađuju.

U zavisnosti od senzora koji će reprodukovati snimak, zavisi i rezolucija snimka. Fotografski snimci imaju bolju rezoluciju nego radarski i skenerski, crnobeli bolju od kolor snimaka, itd. Kada se snimci posmatraju kao digitalna slika u računaru, rezolucija onda predstavlja najmanju jedinicu elementa slike (piksel).

Registrovano zračenje elektromagnetne energije može biti predstavljeno na dva načina: analogno (fotografski) i digitalno (nefotografski).

Analogni način predstavljanja podrazumeva prikaz elektromagnetnog zra- 


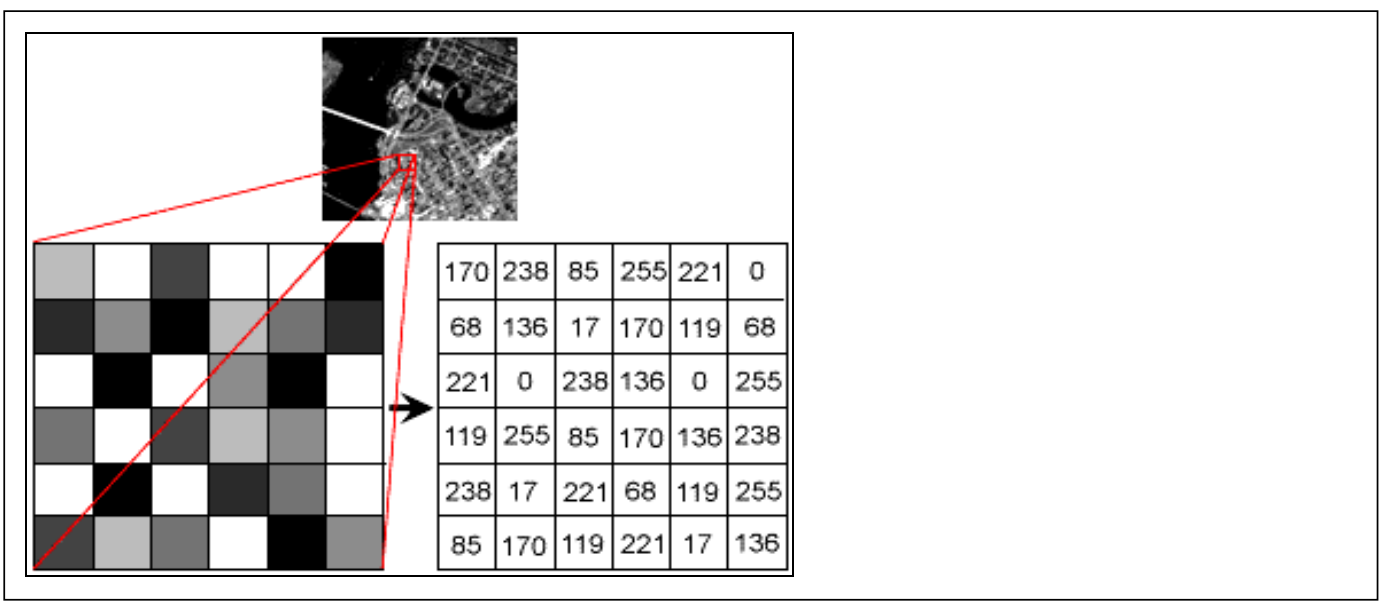

čenja putem fotografija (slika 16), tj. zračenje se detektuje na fotoemulziji.

Digitalni način predstavljanja zračenja EM energije snimkom ogleda se $u$ tome da je slika predstavljena u digitalnoj formi deljenjem u male površine iste veličine, nazvane pikseli (slika 17).

Analogni snimak se posle obrade foto-emulzije javlja kao slika, dok se digitalni, dobijen pomoću radara ili skenera, prvo obrađuje pomoću računara i prikazuje na ekranu, kasnije se ili štampa ili prenosi na film i dalje obrađuje.

Snimak može biti (slika 18): crnobeli; falš-kolor; kolor kompozit; kolor snimak, itd.

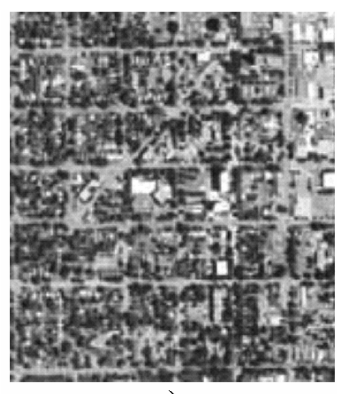

a)

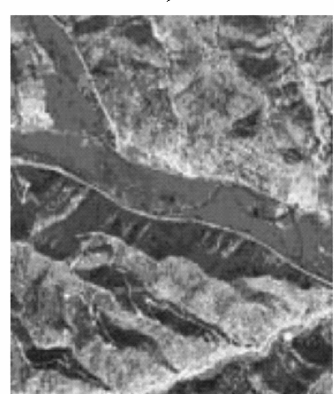

c)

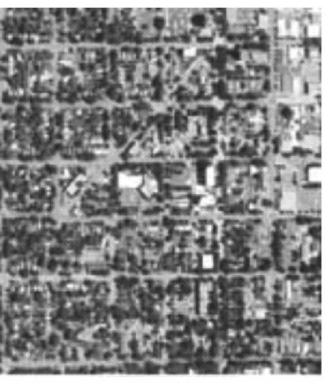

b)

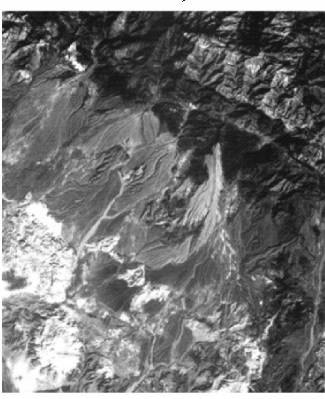

d)
Sl. 18 -Vrste snimaka: a) crnobeli, b) kolor snimak, c) kolor kompozit, d) falš-kolor [8]

Radi što uspešnije interpretacije podataka snimci se obrađuju uz korišćenje veli-

$\begin{array}{ll}\mathrm{veg} & \text { Sl. } 17-\text { Digitalni snimak predstavljen } \\ \mathrm{k} & \text { pikselima i digitalnim brojevima [1] }\end{array}$

broja

programskih paketa namenjenih obradi snimaka dobijenih kao rezultat daljinskih opažanja. Računarskom obradom postižu se znatna poboljšanja snimka. Pomoću takvih softverskih rešenja moguće je poboljšati kvalitet snimka, vršiti geometrijske korekcije, poboljšati kontrast, kao i ujednačavanje svih delova jednog ili više snimaka po intenzitetu osvetljenja i kontrasta.

Najvažnije kvalitativne karakteristike digitalnog snimka, kao i senzora pomoću kojih nastaju, jesu: veličina piksela; prostorna rezolucija; spektralna rezolucija; radiometrijska rezolucija; vremenska rezolucija; geometrijska deformisanost snimka.

\section{Informacija}

Podatak je predstava nekog objekta, pojave ili procesa u realnom vremenu, 
dok se samo obrađeni podatak koji je spreman za upotrebu naziva informacija. Informacije za upotrebu, dobijene daljinskom detekcijom, specifične su u odnosu na druga istraživanja životne sredine. $\mathrm{Na}$ osnovu proizvoda daljinske detekcije može se izvoditi sinteza određenih prostornih podataka, kao i proučavati znatno veća površina prostora nego što je to slučaj sa terenskim istraživanjima. Proizvodi daljinske detekcije su znatno jeftiniji i mnogo racionalniji od samog terenskog rada.

Krajnji rezultat i cilj analize i interpretacije snimaka ili celokupnog procesa daljinske detekcije predstavlja korisna informacija o objektu na terenu. Informacija dobijena primenom daljinske detekcije terena kvalitativno i kvantitativno se razlikuje od rezultata drugih vrsta istraživanja.

Podacima daljinske detekcije nov kvalitet daju i snimanja u nevidljivim delovima spektra elektromagnetne energije. Njeni senzori projektuju se tako da registruju određeni opseg EM zračenja, a kombinacijom više senzora na različitim kanalima (opsezima) registracije može se unaprediti analiza i interpretacija snimljenog sadržaja.

Terenska merenja nikada ne pokrivaju celu površinu istraživanog područja. Primenom postupaka daljinske detekcije, logičke ili instrumentalne analize i interpretacije merenja na snimku obavljaju se na celoj površini snimka. Prohodnost terena, spoljni klimatski uslovi, doba dana i drugi ograničavajući faktori terenskih merenja ne utiču na merenja na snimku u domenu daljinske detekcije.

Kvantitativna i kvalitativna vrednost dobijenih informacija daljinske detekcije, kao nove i drugačije kategorije podataka, nije u suprotnosti i ne isključuje rezultate klasičnih metoda merenja već se međusobno dopunjuju, što ih čini objektivnijim i pouzdanijim. Primenom daljinske detekcije ceo proces geodetskih radova se usmerava i postaje efikasniji, ekonomičniji i racionalniji.

\section{Primena informacija daljinske detekcije za vojne potrebe}

Daljinska detekcija je svojim široko prihvaćenim postupcima i metodama našla veliku primenu u vojnoj delatnosti pri izviđanju, snimanju i praćenju za različite namene. Ovu tvrdnju najbolje mogu dokazati već realizovana istraživanja iz oblasti primene daljinske detekcije $u$ otkrivanju minskih polja.

U ratovima se uvek postavlja veliki broj različitih mina, pojedinačno ili u vidu minskih polja. Po završetku borbenih dejstava mnoge od njih ostaju neotkrivene, pa time i mnogi putevi neprohodni, veliki prostori zapušteni i neobrađeni. Neotkrivene mine uzrokuju na hiljade ljudskih žrtava. Broj postavljenih mina i minskih polja u mnogim zemljama je nepoznat, uglavnom zbog nedostatka dokumentacije o miniranju. Na osnovu istraživanja Genderena, 1997. godine, pretpostavlja se da u Africi ima oko 20 miliona postavljenih mina, od čega samo u Angoli više od milion za koje se zna i oko 15 miliona za koje se pretpostavlja da postoje. I zemlje kao što su Avganistan, Bosna i Hercegovina, Zimbabve, Irak, Kambodža, Laos, Mozambik, Nikaragva, Hrvatska i Srbija ugrožene su minama i neeksplodiranim projektilima zaostalim iz rata. Mine su najčešće ukopane u zemlju i 


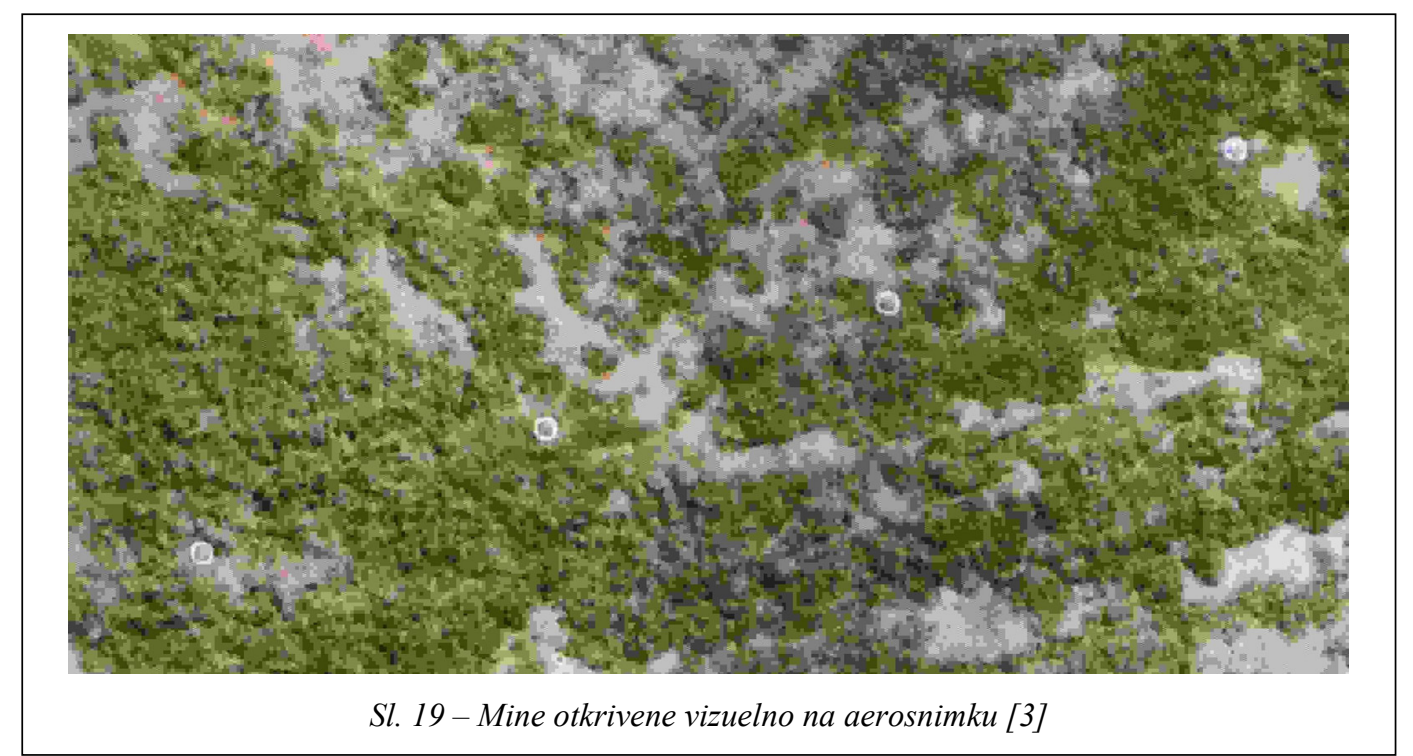

više godina sakrivene vegetacijom. Metodi daljinske detekcije predstavljaju mogućnost njihovog otkrivanja, ali je neophodna primena novih senzora i odgovarajućih metoda interpretacije snimaka.

Više specijalizovanih evropskih institucija izvršilo je u Belgiji pokazna istraživanja miniranih površina metodama daljinske detekcije. Testirani su različiti senzori sa različitih platformi za snimanje. Obrada snimaka i upoređivanje rezultata sa terenskim podacima dali su zadovoljavajuće rezultate, što je povoljno uticalo na organizovanje snimanja miniranih terena u Africi (Mozambi$\mathrm{ku}$ ). U okviru primene metoda daljinske detekcije u otkrivanju mina u periodu od kraja 1997. do kraja 1999. godine u Mozambiku je simultano korišćeno 6 različitih senzora (dva u vidljivom i bliskom IC, dva u termalnom IC i dva u mikrotalasnom području elektromagnetskog spektra).

Snimci u vidljivom delu spektra korišćeni su za vizuelnu interpretaciju i računarski podržanu analizu. Pri analizi su korišćene karakteristike tla i vegetacije.
Mesta sa ukopanim minama imaju drugačiju teksturu i vlažnost tla, što je uzrokovalo poremećaj strukture tla i time uočljivo razlikovanje od tla na kojem nema mina, što se može videti na slici 19.

$\mathrm{Na}$ uvećanom delu IC kolor aerosnimka dobro se uočava pozicija i veličina mine (slika 20). Ako je poznat koordinatni sistem moguće je i približno odrediti veličinu mine. Snimanja u termalnom IC delu spektra $(8-14 \mu \mathrm{m})$ vršena su senzorom CA-860 IRSL. To je IC linijski skener koji postiže vrlo veliku rezoluciju od 0,25 miliradijana, pomoću kojeg se mogu otkriti objekti od $7 \mathrm{~cm}$ sa visine od 300 metara.

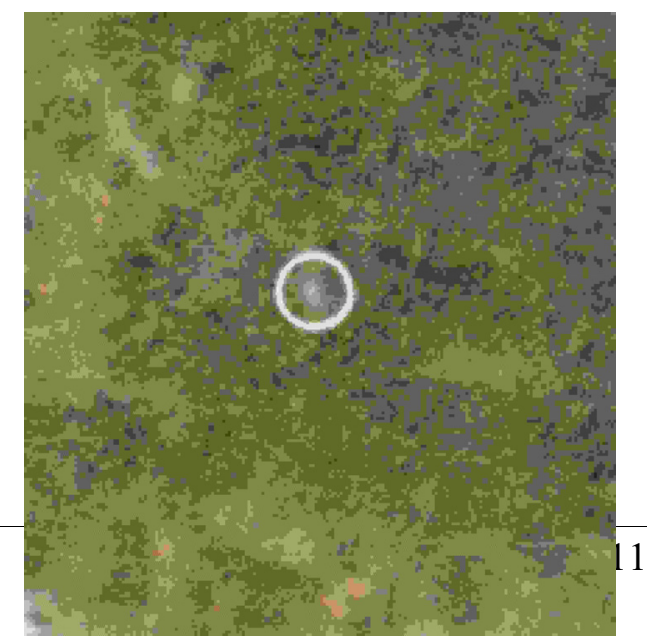


Sl. 20 - Uočavanje mesta i veličine mine na IC kolor snimku [3]

Senzor može otkriti objekte čija se temperatura razlikuje od temperature okolnih objekata i terena do $0,2^{\circ} \mathrm{C}$. Pošto je temperatura mina od metala ili plastike različita od temperature okolnog zemljišta, mogu se uspešno identifikovati. Najuspešniji su rezultati snimanja obavljeni po sunčanom danu 2-3 sata pre i posle izlaska Sunca, jer se mine, zbog male mase u odnosu na okolinu, ujutro brže zagrevaju Sunčevom energijom, a posle zalaska Sunca brže hlade od okoline.

Od mikrotalasnih senzora planirani su radari sa H-kanalom i visokom prostornom rezolucijom od $50 \mathrm{~cm}$ i R-kanalom, čiji zraci prodiru kroz tlo i vegetaciju do polovine talasne dužine, odnosno do približno $35 \mathrm{~cm}$. Kako je većina mina ukopana na dubini od $10 \mathrm{~cm}$, moguće je otkrivanje mina upotrebom ove vrste senzora. Optički senzori su, takođe, uspešno korišćeni pri ovim istraživanjima.

Pored sprovedenih snimanja, za analizu promena u vegetaciji, korišćeni su i različiti postojeći satelitski snimci. Terenska provera obavljena je na podlogama IC snimaka rezolucije $2 \mathrm{~cm}$, koji su geokodirani u digitalne karte razmera 1:2000 do 1:5000, koje su kompatibilne sa standardnom GIS bazom podataka. Pri ovim istraživanjima korisnim su se pokazale i digitalne ortofoto karte krupnijeg razmera.

\section{Zaključak}

Mali je broj metoda, naučnih disciplina ili naučnih oblasti koje su imale tako brz i eksplozivan razvoj kao daljinska detekcija.

$\mathrm{Na}$ daljinskoj detekciji danas u svetu radi veliki broj stručnjaka različitih specijal- nosti. Tehnologija snimanja, oprema, kompjuterski programi, postupci i područja primene neprekidno se usavršavaju i proširuju. Samim tim, obimna literatura brzo biva prevaziđena i zastarela. Principi i osnovne postavke, međutim, ostaju isti.

Savremena sredstva komunikacije, posebno internet, omogućavaju široku razmenu informacija o razvoju daljinske detekcije, ekspertima i institucijama koje se time bave, organizacijama koje obavljaju kosmička snimanja, kao i komercijalnu distribuciju snimaka.

Daljinska detekcija postaje sve značajnija i nezaobilazna metoda prikupljanja informacija o prostoru za vojne potrebe. Sve vodeće satelitske misije i programi, pored praćenja i snimanja stanja najrazličitijih prirodnih i društvenih pojava, mogu uspešno da zadovolje sve zahtevnije zadatke u vojnoj delatnosti.

Iskustva iz istraživanja sprovedenih u Belgiji i Mozambiku, kao i neka kasnija, mogu biti pomoć i podstrek za primenu metoda daljinske detekcije pri otkrivanju mina $\mathrm{i}$ neeksplodiranih projektila na teritoriji Srbije i susednih zemalja, postavljenih za vreme ratnih dešavanja $u$ poslednjoj deceniji prošlog veka. Pored toga, metodi daljinske detekcije mogu se primenjivati i za razne druge potrebe.

\section{Literatura:}

[1] Canada centre for remote sensing: Fundamentals of Remote Sensing, Natural Resources Canada, 2002.

[2] Karsten, J.: Orthoimages and DEMs by QuickBird and IKONOS, EARSeL Symposium Prague, 2002.

[3] Oluić, M.: Snimanje i istraživanje Zemlje iz svemira, satelitisenzori-primjena, Hrvatska akademija znanosti i umjetnosti, Zagreb, 2001.

[4] Pavlović, R., Čupković, T., Marković, M.: Daljiinska detekcija, Rudarsko-geološki fakultet, Beograd, 2001.

[5] Regodić, M.: Ažurirane radne karte daljinskom detekcijom terena, doktorska disertacija, Vojna akademija, Beograd, 2007.

[6] htpp://images.google.com/images

[7] htpp://www.grf.bg.ac.yu/mm/files/learnmat/42Fotogrametrija $\% 201 \% 20 \% 20$ Platforme $\% 20$ Kamere $\% 201 \% 20$ senzori.pdf 
[8] htpp://www.spaceimage.com

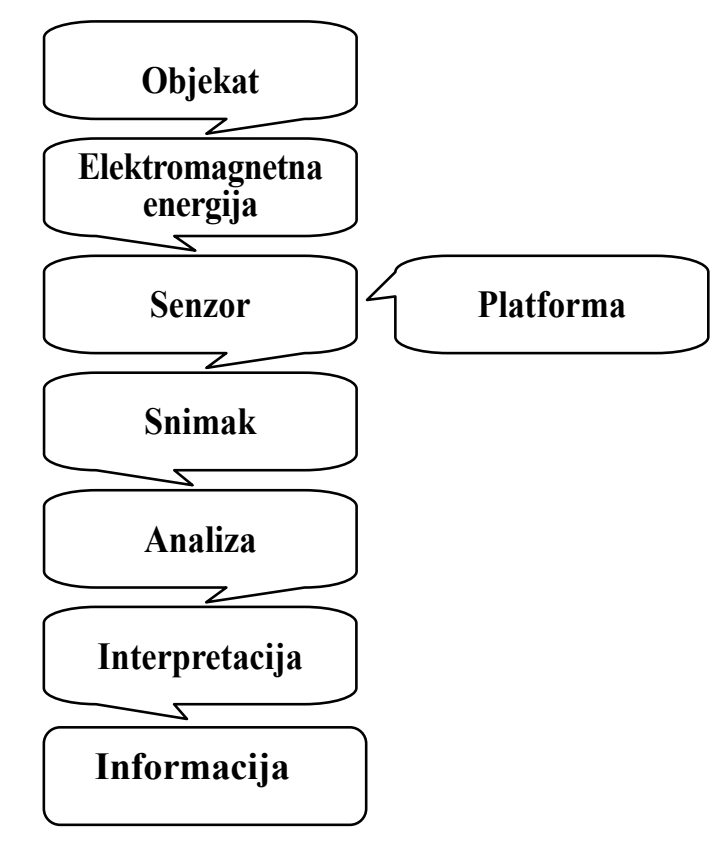

Sl. 1 - Princip daljinske detekcije [5] 


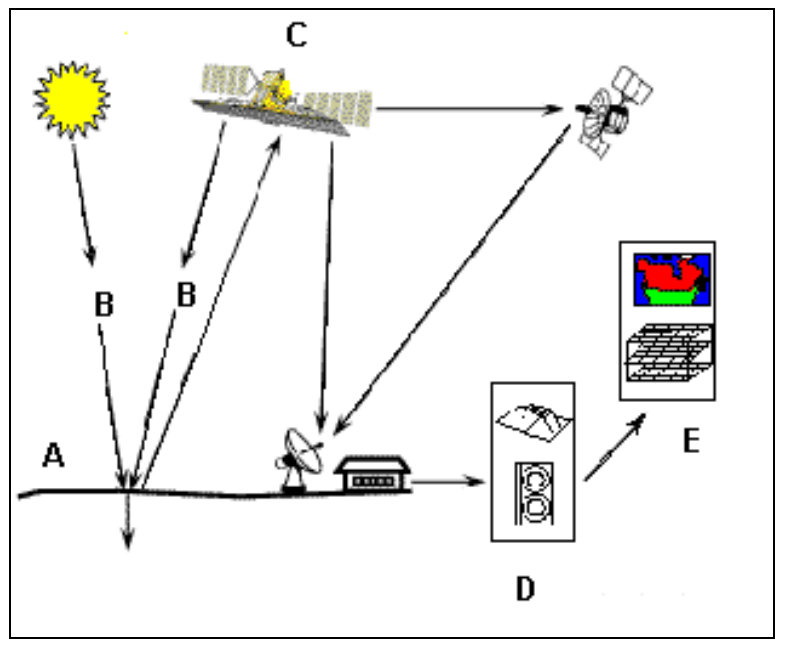

Sl. 2 - Osnovni elementi daljinske detekcije [2]

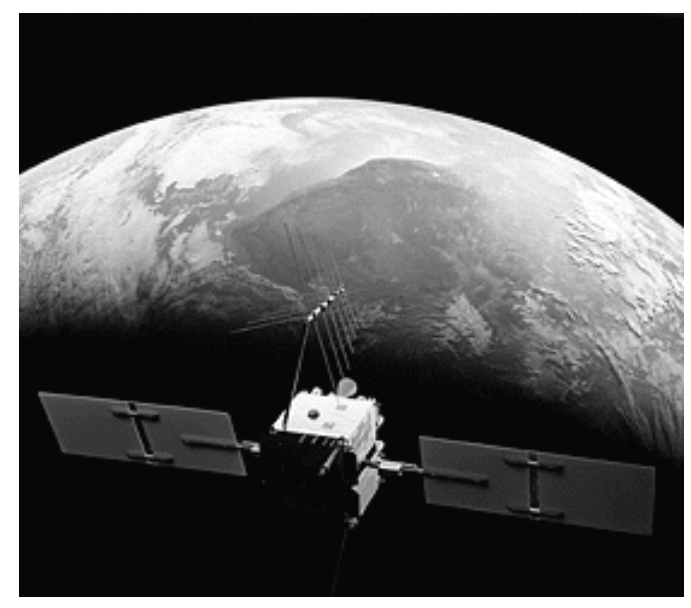

Sl. 3 - Predmet istraživanja daljinske detekcije [6] 


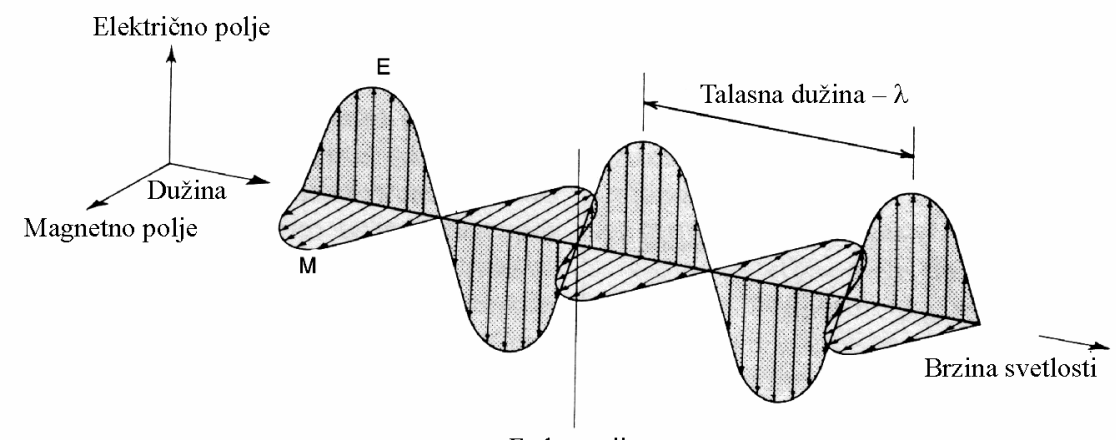

Frekvencija

Sl. 4 - Komponente elektromagnetne energije [6]

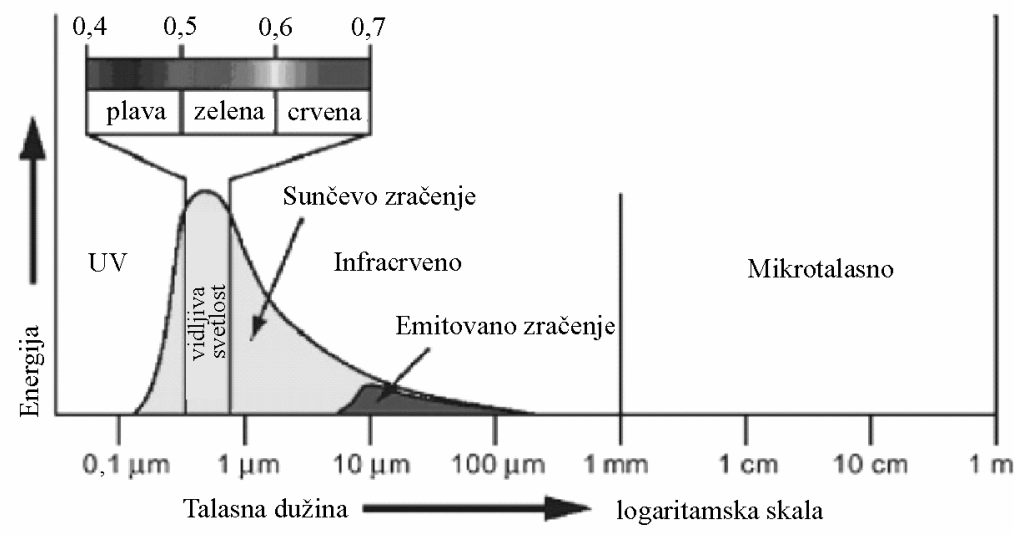

Sl. 5 - Spektar elektromagnetne energije u prirodi [4]

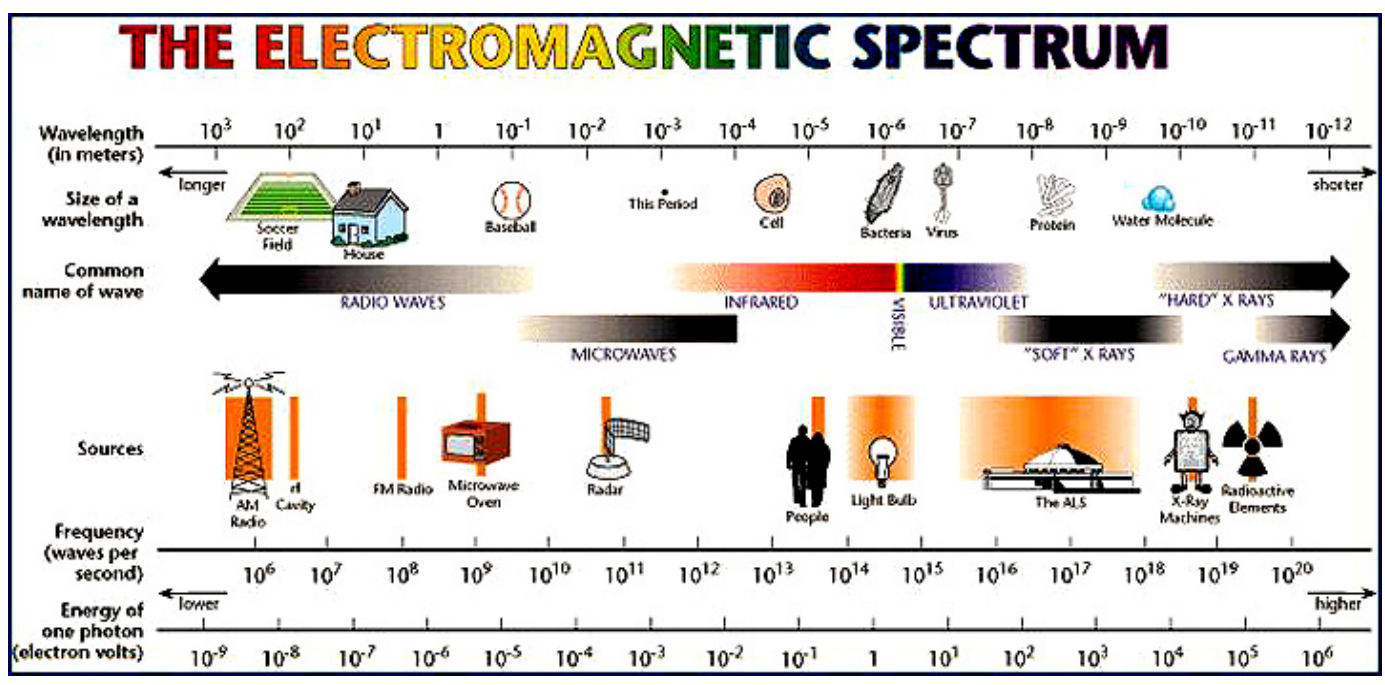


Sl. 6-Međusobni odnos između veličina koje karakterišu EM spektar [7]

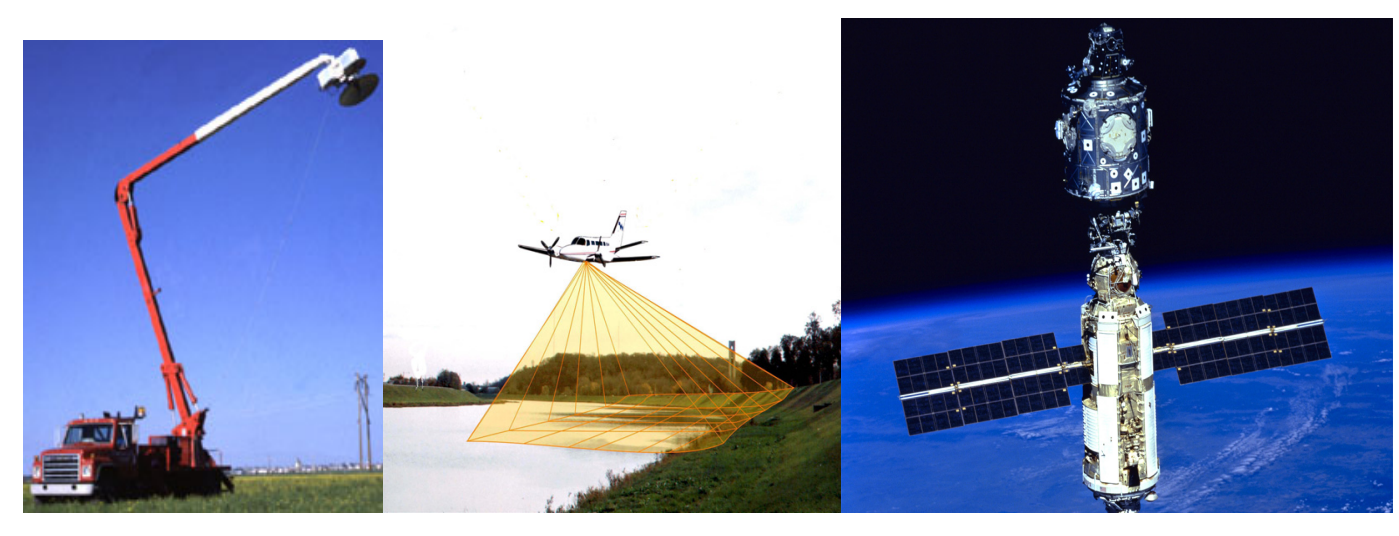

Sl. 7 - Terestričke platforme, aeroplatforme, kosmičke platforme [6]

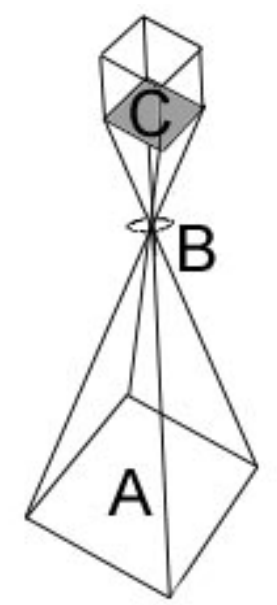

Sl. 8 - Koncept aerofotogrametrijskog snimanja [1] 

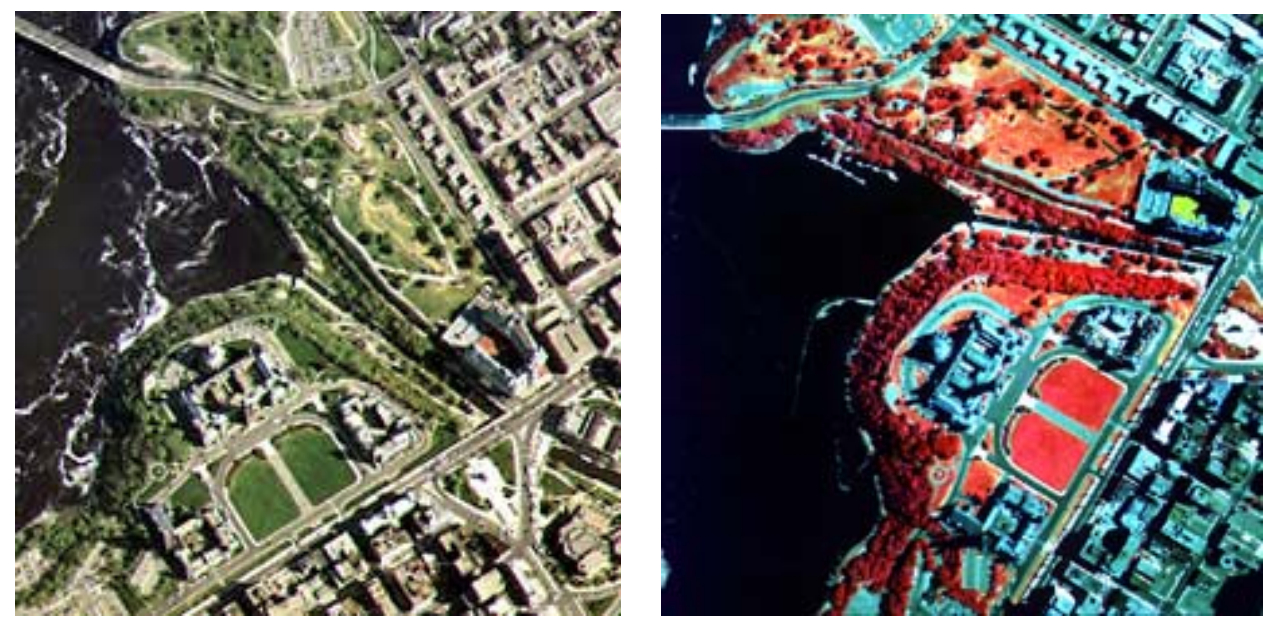

Sl. 9 - Kolor i falš-kolor snimak nastao skeniranjem aerofotografije [8]
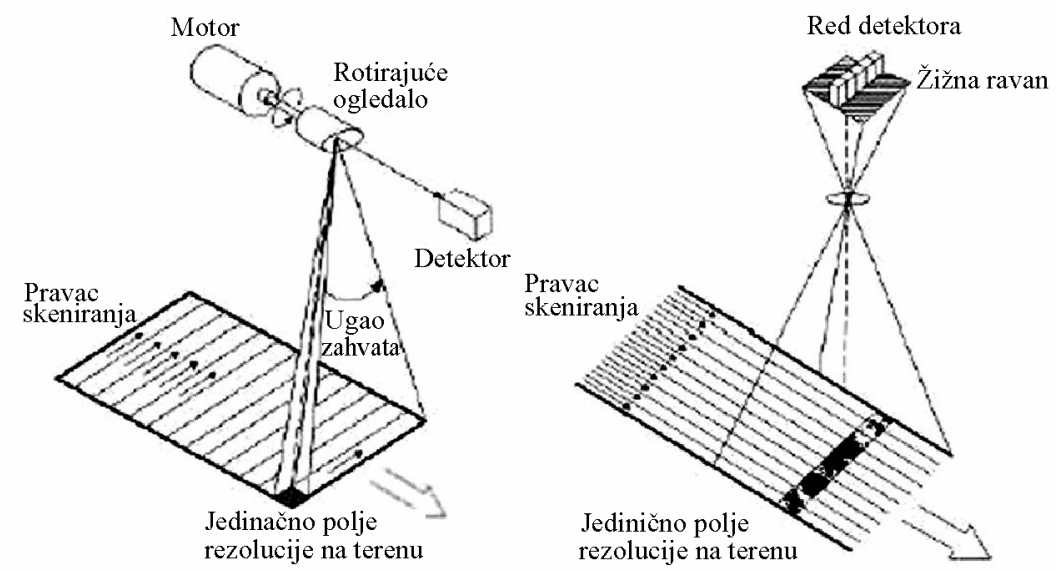

A) Poprečni skener

B) Uzdužni skener

Sl. 10 - Tipovi linijskih skenera [7] 


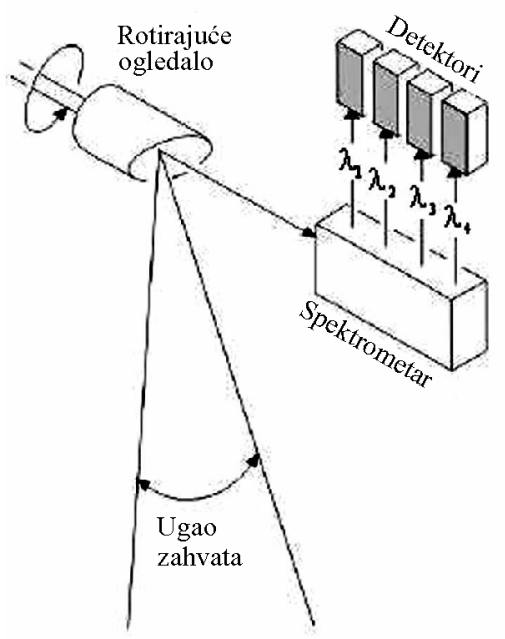

A) Poprečni multispektralni skener

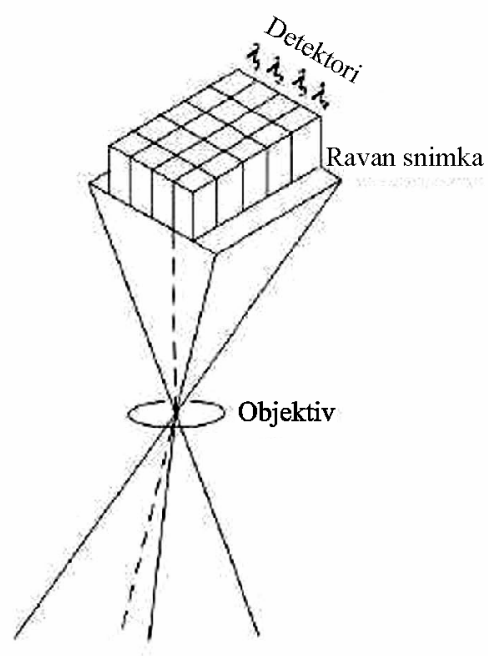

B) Uzdužni multispektralni skener

Sl. 11 - Multispektralni skeneri [7]
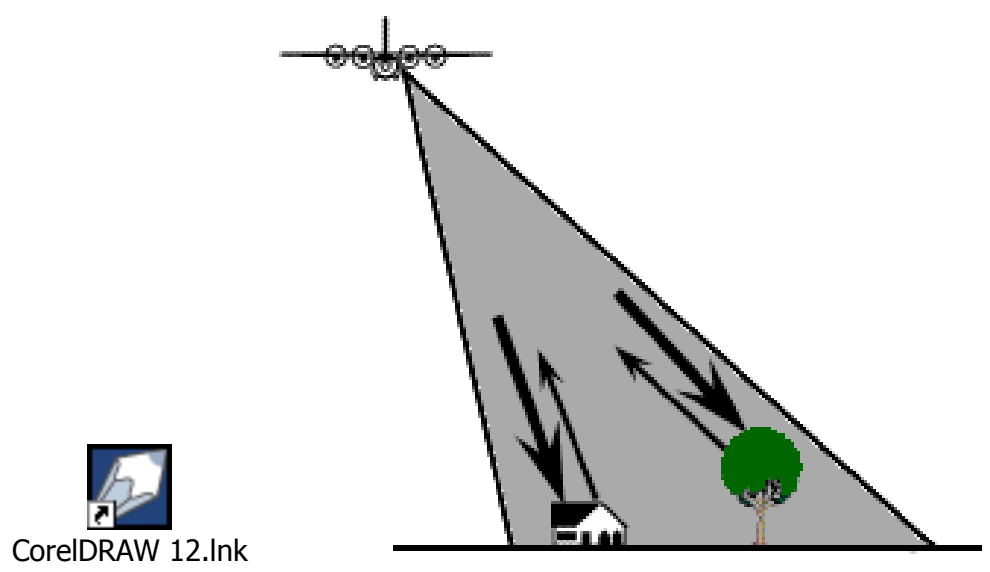

Sl. 12 - Radarsko snimanje terena [1] 

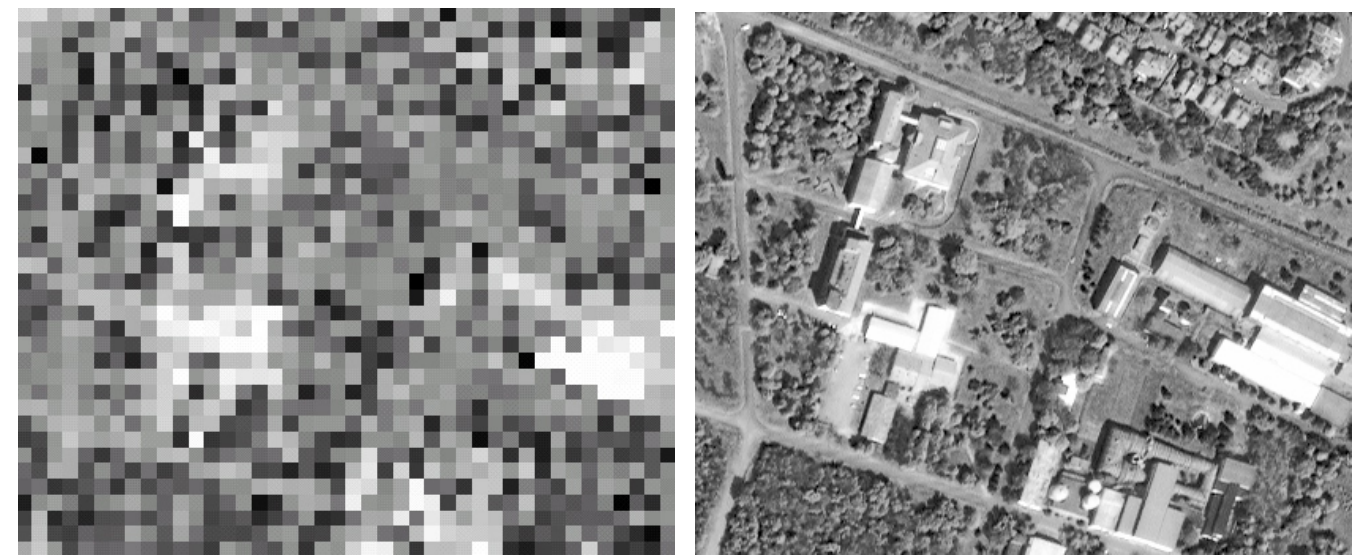

Sl. 13 - Snimak loše rezolucije (IKONOS - $10 \mathrm{~m})$ i snimak dobre rezolucije (IKONOS - 1m) [5]

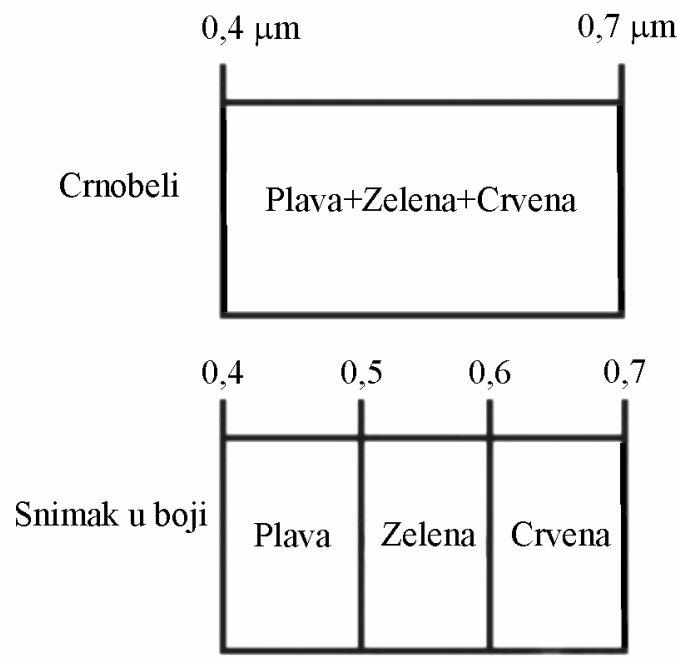

Sl. 14 - Spektralna rezolucija crnobelog i kolor snimka [4] 

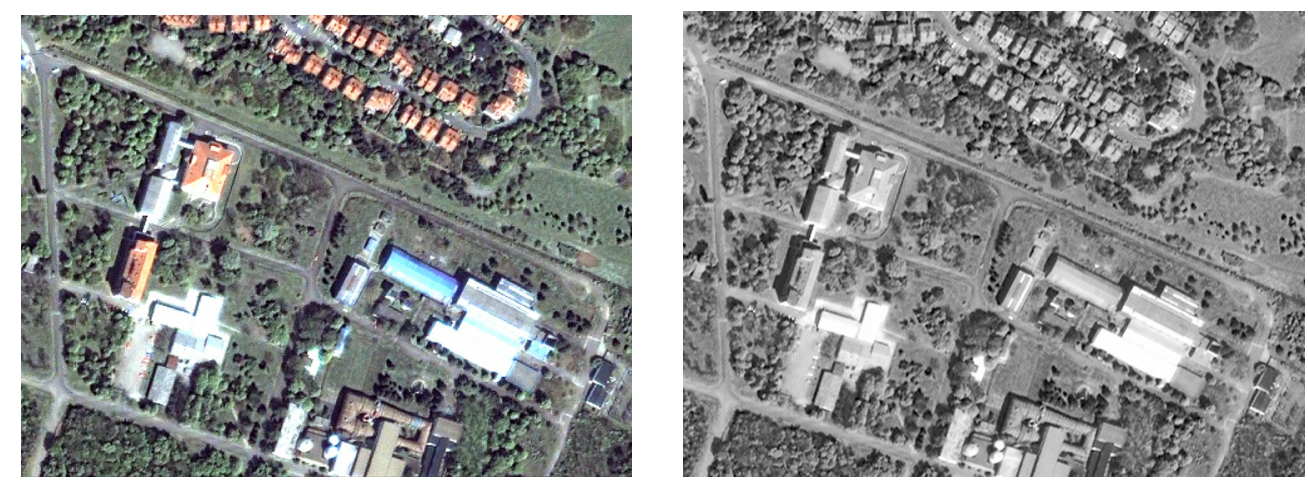

Sl. 15 - Satelitski snimci, kolor i crnobeli [5]

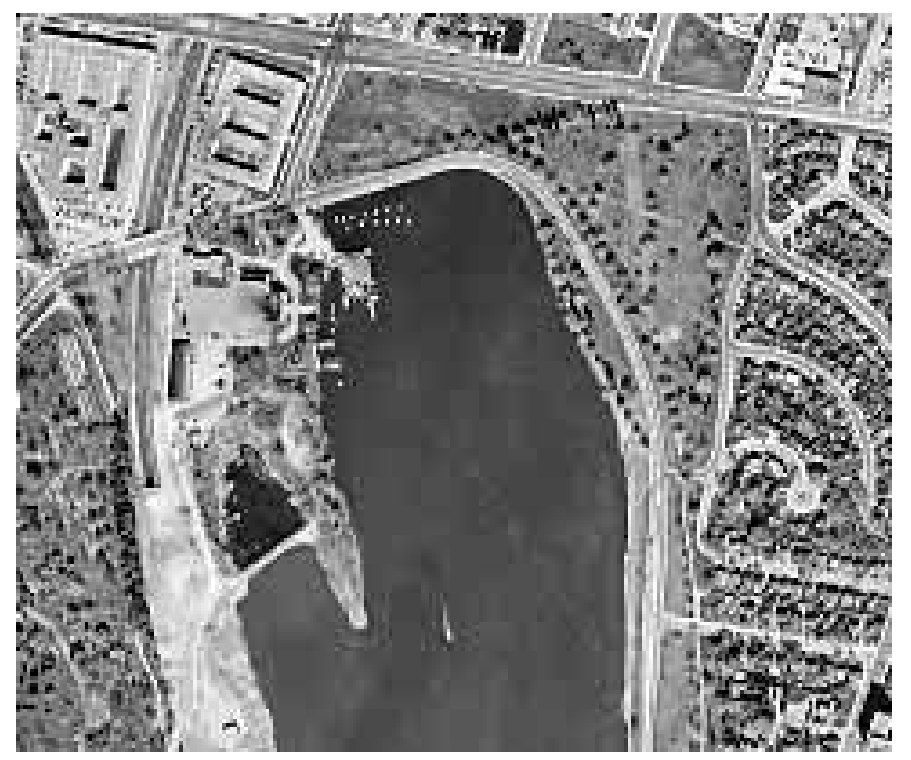

Sl. 16 - Zračenje EM spektra registrovano kao fotografija [1] 


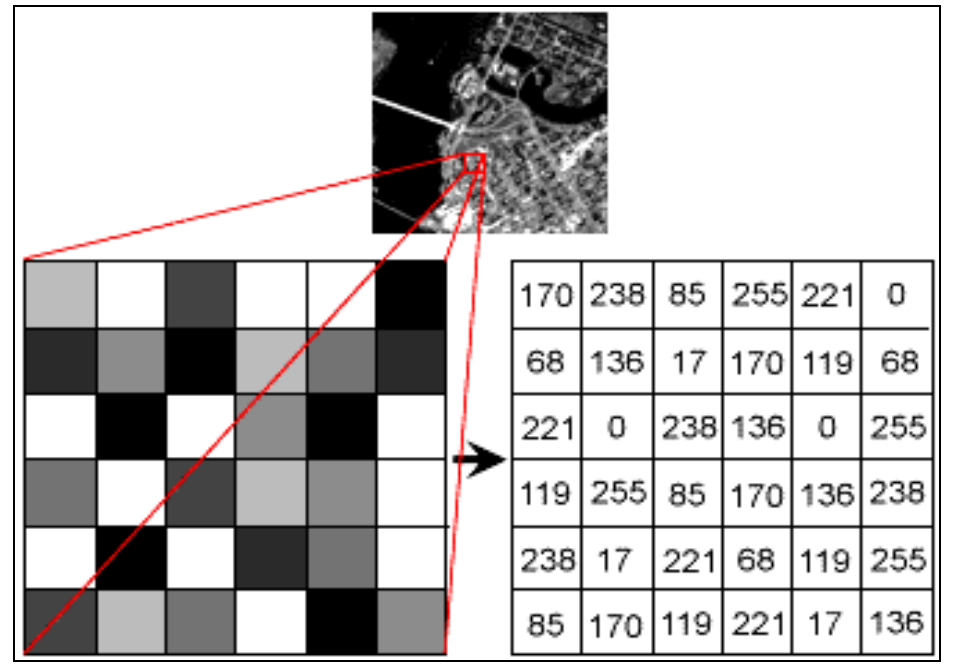

Sl. 17 - Digitalni snimak predstavljen pikselima i digitalnim brojevima [1] 


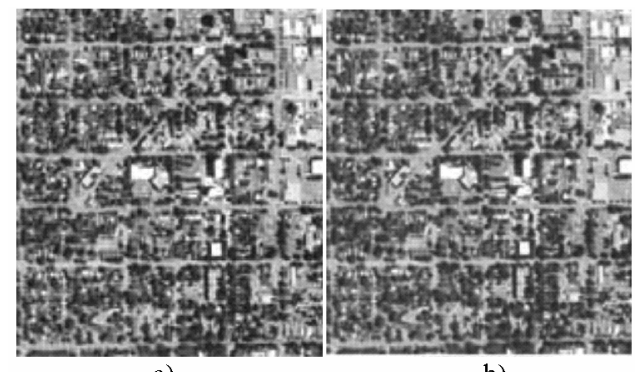

a)

b)

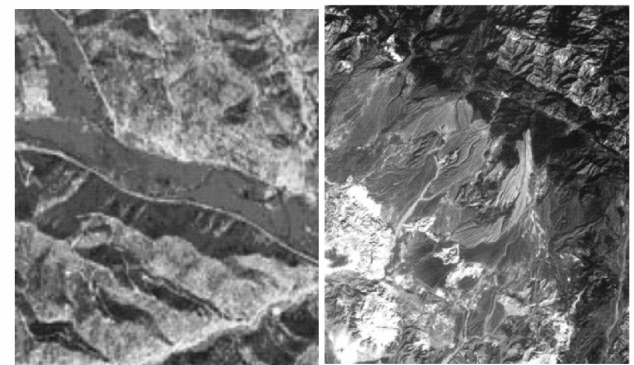

c)

d)

Sl. 18 - Vrste snimaka: a) crnobeli, b) kolor snimak, c) kolor kompozit, d) falš-kolor [8]

Sl. 19 - Mine otkrivene vizuelno na aerosnimku [3]

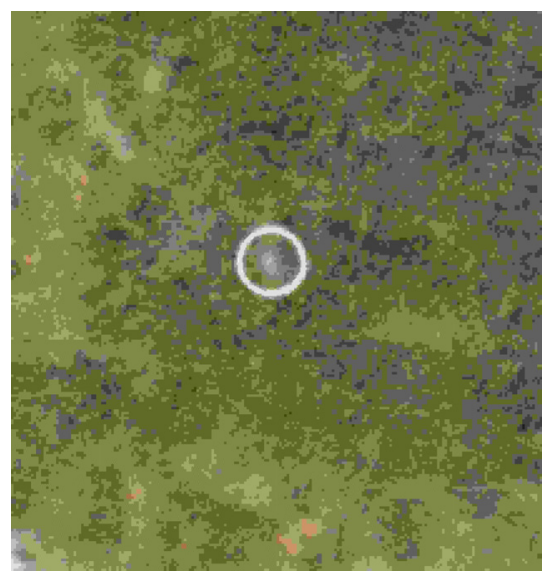




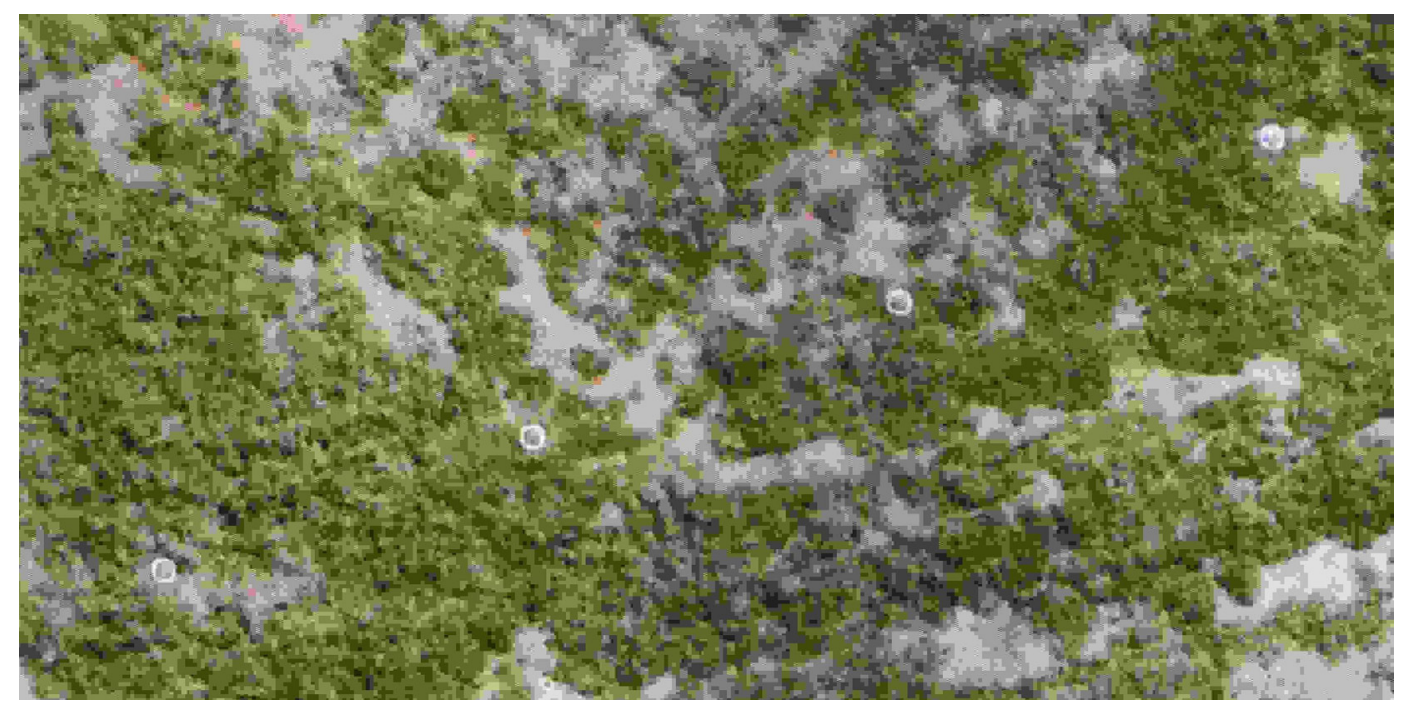

Sl. 20 - Uočavanje mesta i veličine mine na IC kolor snimku [3] 